\title{
Constraint on foreland basin migration in the Zagros mountain belt using Sr isotope stratigraphy
}

\author{
Mortaza Pirouz,* Guy Simpson $\uparrow$ and Massimo Chiaradia $\dagger$ \\ *Division of Geological and Planetary Sciences, California Institute of Technology, Pasadena, CA, USA \\ $\dagger$ Section of Earth and environmental Sciences, University of Geneva, Geneva, Switzerland
}

\begin{abstract}
We have constrained the time-space migration of the Zagros foredeep basin by performing Sr isotope stratigraphy on 31 samples of marine macrofossils from Neogene sediments now exposed in the $\mathrm{Za}$ gros mountain belt in southwest Iran. Our results show that these deposits (represented mainly by the Mishan Formation) are strongly diachronous, with ages ranging between $17.2 \pm 0.2$ and $1.1 \pm 0.1 \mathrm{Ma}$. These deposits are older in the west (Dezful region) and become progressively younger towards the south and the south-east (Fars region). Our results show that the marine foredeep was replaced by a fluvial sedimentary environment between $c a .14$ and $12 \mathrm{Ma}$ in the western sector, while this occurred between $c a$. 8 and $1 \mathrm{Ma}$ in the eastern sector, becoming younger towards the south. These results enable us to show that the foreland basin migrated perpendicular to the orogen at rates of between 17.5 and $50 \mathrm{~mm}_{\text {year }}{ }^{-1}$ throughout the Neogene, exceeding migration rates in the Alps, Pyrenees, Apennines and Himalayan foreland basins. The sporadically elevated rates in the Zagros appear to be related to times when major widely spaced pre-existing basement faults became reactivated. Finally, our results, when combined with published data, have enabled us to establish a new chronostratigraphic diagram for the Neogene portion of the Zagros foreland basin. Our study highlights that foreland basins are extremely dynamic settings where depocentres and palaeoenvironments may change rapidly in both time and space in relation to migrating deformation.
\end{abstract}

\section{INTRODUCTION}

The Zagros region of south western Iran contains one of the largest and most impressive active foreland basin systems on Earth, renowned especially for its abundant hydrocarbon reserves, massive salt diapirs and glaciers, soaring anticlines, multiple detachment folding and textbook modern carbonate system (James \& Wynd, 1965; Kent, 1979; Koop et al., 1982; DeCelles \& Currie, 1996; Talbot \& Alavi, 1996; Alavi, 2007). However, compared to the intensely studied foreland basins of Europe (Ricci Lucchi, 1986; Allen et al., 1991; Sinclair \& Allen, 1992; Sinclair, 1997a,b; Pfiffner et al., 2002; Vergés et al., 2002), North America (Poole, 1974; Cross, 1986; DeCelles \& Currie, 1996; DeCelles, 2004; Horton et al., 2004; Painter \& Carrapa, 2013) and the Himalayas (Lavé \& Avouac, 2001; Avouac, 2003; Bollinger et al., 2004; Mugnier \& Huyghe, 2006), relatively little is known about the Zagros foreland basin (see however Homke et al., 2004; Fakhari et al., 2008; Gavillot et al., 2010; Pirouz et al., 2011; Saura et al., 2011; Khadivi et al., 2012, 2010). In this paper, we focus on one aspect of the Zagros that is particularly poorly constrained, namely the age of

Correspondence: Mortaza Pirouz, Division of Geological and Planetary Sciences, California Institute of Technology, MC 100-23, 1200 E. California Blvd., Pasadena, CA 91125, USA. E-mail:mpirouz@caltech.edu sediments comprising the collision-related foredeep sedimentary basin. We hope that by better constraining the time-space evolution of the foredeep deposits and its migration rate in a well exposed and active foreland basin such as the Zagros, we may enhance our ability to successfully interpret ancient foredeep deposits such as those normally studied in more accessible regions of the world.

The foredeep deposits of the Zagros foreland basin are mainly represented by the Mishan formation, which traditionally has been assigned to the Early-Middle Miocene over the entire Zagros (James \& Wynd, 1965; Setudehnia, 1972). There are a number of points which make this 'layercake' regional correlation unlikely. First, recent magnetostratigraphic studies have demonstrated that the fluvial wedgetop deposits overlying the Mishan formation (comprising the Razak, Agha Jari and Bakhtiari formations) are diachronous across the region, becoming progressively younger from the north towards the Persian Gulf in the south (Homke et al., 2004; Khadivi et al., 2010). Second, our own work has shown that there is a close similarity between the depositional environments interpreted for Neogene deposits observed in any one vertical section and the modern depositional environments observed along a north-south profile, a feature which also implies diachroneity (Pirouz et al., 2011). Third, based on our current understanding of how foreland basins migrate progressively with time as mountain belts widen, it is hard to imagine how the Zagros foredeep deposits 
could all be of middle Miocene age. Rather, one would normally expect the deposits to be oldest in the north and to be very young adjacent to the modern foredeep, represented by the Persian Gulf in the south.

In this study, we date the marine Zagros foredeep (Mishan Fm.) deposits for the first time using Strontium isotope stratigraphy. The Mishan deposits contain few diagnostic macro- and micro-fossils that provide independent age constraints (e.g. Neoalveolina melo curdica, Ammonia becearri, and Operculina complanata in the proximal Interior Fars and Miogypsina cf. globulina, Archaias sp. and Tubucellaria sp. in the distal Interior Fars representing Middle to Late Miocene respectively). The $\mathrm{Sr}$ isotope technique is a potentially powerful dating method made possible by the rapid monotonic change in ${ }^{87} \mathrm{Sr} /{ }^{86} \mathrm{Sr}$ values during the Neogene. This method has already been used with success in the Zagros to date the Oligo-Miocene Asmari Formation (Ehrenberg et al., 2007; van Buchem et al., 2010; Saura et al., 2011). Our study fills a gap between these results, and the magnetostratigraphic data for the overlying continental deposits (Homke et al., 2004; Emami, 2008; Khadivi et al., 2010). The results of our study, along with previously published age constraints, enable us to establish a new chronostratigraphic chart for the Zagros region during the Neogene. In addition, the results let us calculate propagation rates for the Zagros foreland basin and provide new constraints on how the Zagros mountain belt and its adjacent foreland basin evolved in time and space.

\section{GEOLOGICAL SETTING OF THE ZAGROS BASIN}

The Zagros foreland basin (SW Iran) occurs along the northern margin of the Arabian plate that is currently colliding with the Eurasian plate (Takin, 1972; Berberian \& King, 1981; Talbot \& Alavi, 1996) (Fig. 1). The Zagros region and the stable Arabian platform were part of Gondwana during the entire Palaeozoic (Stocklin, 1968; Berberian \& King, 1981; Sepehr \& Cosgrove, 2004). This region rifted off Gondwana during the Permo-Trias to form the Neo-Tethys oceanic basin. Northern part of the Arabia developed as a passive margin between the Jurassic and the Early Cretaceous before subduction began in the Late Cretaceous. Subduction of the Arabian margin beneath the Eurasian plate continued into the Tertiary until the Early Miocene when continent-continent collision began, which has continued until present day (Berberian, 1995; Talbot \& Alavi, 1996; Alavi, 2004; Homke et al., 2004; Agard et al., 2005; Mouthereau et al., 2007; Allen \& Armstrong, 2008; Khadivi et al., 2010). Today, the Arabian plate moves at an average rate of $c a .20 \mathrm{~mm} \mathrm{year}^{-1}$ towards Eurasia (Tatar et al., 2002; Hessami et al., 2006; Reilinger et al., 2006; Walpersdorf et al., 2006) resulting in $10 \mathrm{~mm} \mathrm{year}^{-1}$ of pure shortening (Tatar et al., 2002), regional surface uplift and active subsidence in the foreland.

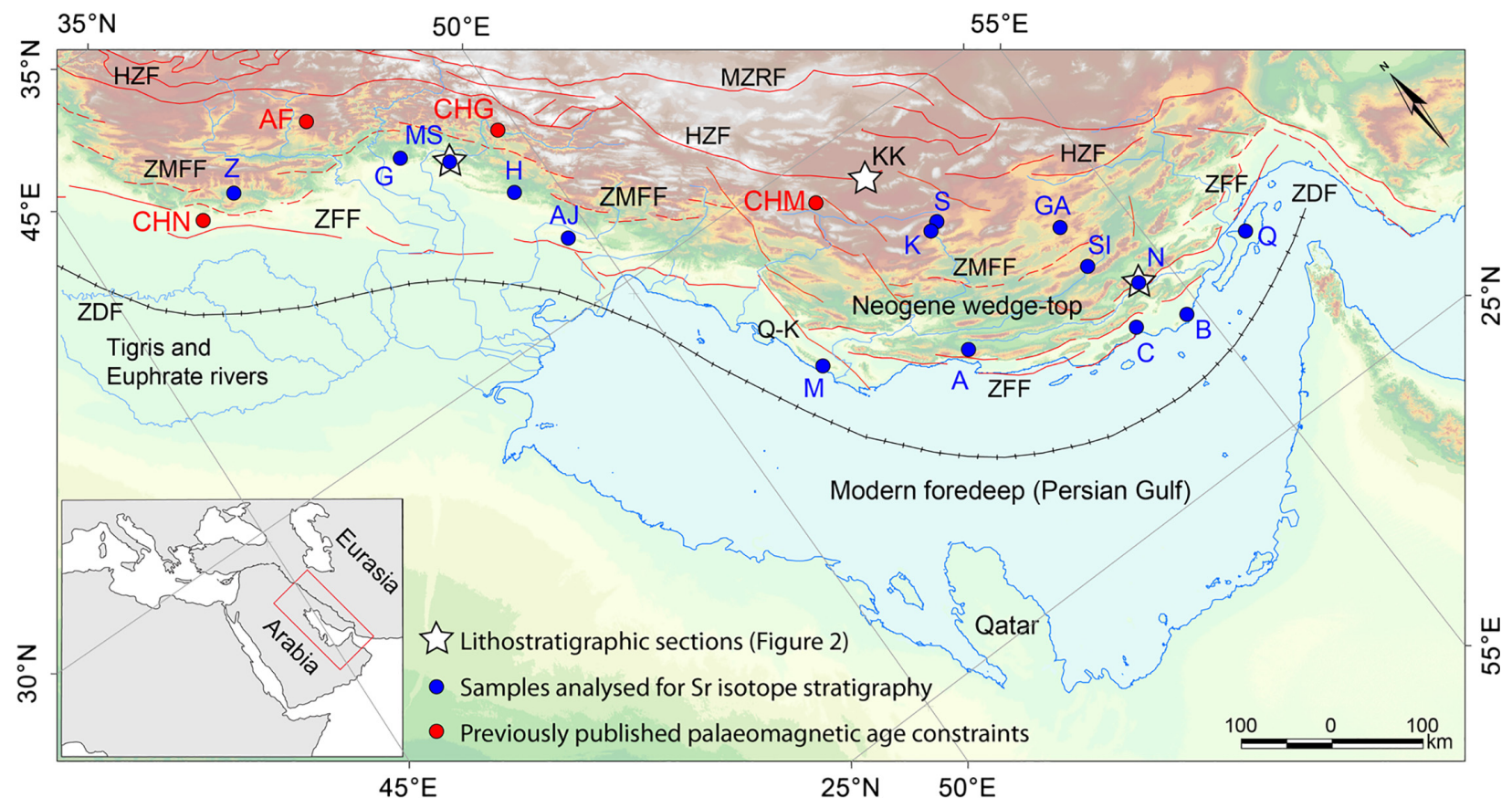

Fig. 1. Map showing locations of samples analyzed for strontium isotope stratigraphy (blue dots), previously published palaeomagnetic age constraints (red dots) and measured lithostratigraphic sections (white stars) across the Zagros region. Abbreviations are defined as follows: A, Asaluyeh; AF, Afrineh; AJ, Agha Jari; B, Bostaneh; C, Charak; CHG, Chaman goli; CHM, Chahar makan; CHN, Changuleh; G, Gatvand; GA, Gach; H, Haftkel; K, Kaftar; KK, Kaharak; M, Mand; MS, Masjed Solayman; N, Nakh; Q Qeshm; S, Sepidar; SI, Siah; Z, Zarinabad; MZRF, Main Zagros Reverse Fault; HZF, High Zagros Fault; ZMFF, Zagros Mountain Frontal Fault; ZFF, Zagros Foredeep Fault; Q-K, Qatar-Kazerun Lineament; ZDF, Zagros Deformation Front. 


\section{NEOGENE-RECENT ZAGROS FORELAND BASIN STRATIGRAPHY}

The Neogene-Recent foreland basin displays a broadly upward-coarsening regressive mega-cycle that records the progressive uplift and southward migration of the Zagros mountain belt through time (Fig. 2), as has been recognized by numerous authors (Alavi, 2004, 2007; Fakhari et al., 2008; Heydari, 2008; Khadivi et al., 2010; Pirouz et al., 2011). For our study, the base of the foreland basin sequence is considered to be marked by the Gachsaran Formation, which includes about $c a .1000 \mathrm{~m}$ of clastic, evaporitic deposits and coloured marl interbeds. The depositional environment of the Gachsaran Formation is mostly sabkha and supratidal, which was sometimes replaced by shallow restricted marine conditions. This lithofacies association is known as the Razak Formation in the High Zagros region and the interior Fars area and consists of a basal conglomerate bed overlain by red mud- stones along with siltstone interbeds, sandstone bodies and bioclastic limestones (Fig. 2) (Pirouz et al., 2011). The Gachsaran Formation separates the Neogene foreland basin deposits from the older platform carbonates. These evaporitic units are overlain by the Mishan Formation (the main focus of this study), with a thickness that varies between $c a .50$ and $1600 \mathrm{~m}$, increasing towards the east (James \& Wynd, 1965; Setudehnia, 1972; Kashfi, 1980; Motiei, 1993). The Mishan Formation can be divided into three main lithofacies associations $\left(\mathrm{MN}_{\mathrm{L}}\right.$, $\mathrm{MN}_{\mathrm{R}}, \mathrm{MN}_{\mathrm{M}}$ ) on the basis of interpreted depositional environment (Pirouz et al., 2011). The $\mathrm{MN}_{\mathrm{L}}$ lithofacies association consists of evaporite deposits, red mudstones, green marls, sandstones, sandy limestones and limestones (including bryozoans, ostracods and foraminifera) and has a maximum thickness of $c a .300 \mathrm{~m}$. This lithofacies association is interpreted to be deposited in a restricted environment such as lagoon. The $\mathrm{MN}_{\mathrm{R}}$ lithofacies association, commonly known as the Guri Member, consists of

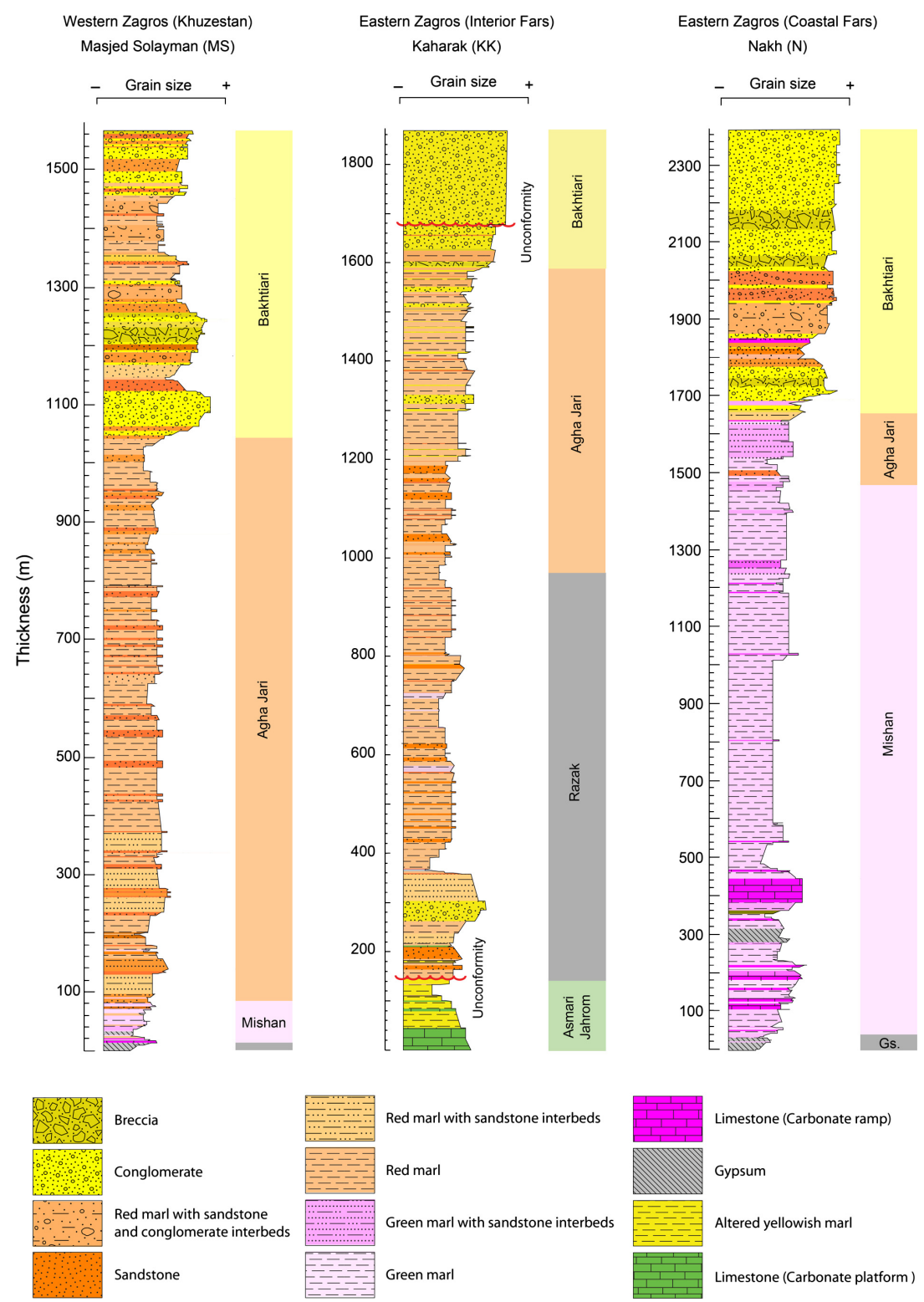

Fig. 2. Three representative lithostratigraphic sections (Masjed Solayman, Kaharak and Nakh) of the Zagros foreland basin. The location of these stratigraphic sections is shown on the Fig. 1. 
massive to thick-bedded reefal limestones (including algae, gastropods, bryozoans and benthic foraminifera) and grainstones. It is best developed east of the Qatar-Kazerun lineament in the Fars region. This lithofacies association is interpreted to be deposited on the inner ramp of a shallow marine environment. This massive limestone is replaced by green marls with thin limestone interbeds west of the Qatar-Kazerun fault zone. The upper lithofacies association $\mathrm{MN}_{\mathrm{M}}$ of the Mishan Formation contains thickly bedded green marls (containing small benthic foraminifera) with thin limestone and oyster beds. This lithofacies association is interpreted to be deposited in the deeper part (outer ramp) of a shallow marine basin. In a vertical section, the Mishan deposits are overlain by the Agha Jari continental to estuarine deposits (Fig. 2). These dominantly fluvial sediments were most likely deposited in a meandering river system with high sinuosity at the base to possibly low sinuosity at the top (Pirouz et al., 2011). The repeated red sandstone and mudstones of the Agha Jari Formation are overlain by the Bakhtiari conglomerates (Fig. 2) that are interpreted to be deposited in a braided fluvial depositional system (James \& Wynd, 1965; Fakhari et al., 2008; Pirouz et al., 2011).

\section{STRONTIUM ISOTOPE STRATIGRAPHY}

The $\mathrm{Sr}$ isotope dating method is based on direct comparison between measured ${ }^{87} \mathrm{Sr} /{ }^{86} \mathrm{Sr}$ from a sample and the known variation in seawater ${ }^{87} \mathrm{Sr} /{ }^{86} \mathrm{Sr}$ calibrated through time (Burke et al., 1982; Elderfield, 1986; McArthur et al., 2001; McArthur \& Howarth, 2004). This method therefore requires measurement of ${ }^{87} \mathrm{Sr} /{ }^{86} \mathrm{Sr}$ in minerals that precipitated from seawater and have resisted diagenetic alteration of the original ${ }^{87} \mathrm{Sr} /{ }^{86} \mathrm{Sr}$ value. Some intervals of the geological timescale are particularly favourable for this method because they show high, nearly constant rates of change of marine ${ }^{87} \mathrm{Sr} /{ }^{86} \mathrm{Sr}$ values. The variation in the ${ }^{87} \mathrm{Sr} /{ }^{86} \mathrm{Sr}$ ratio during the Neogene is the most promising period for $\mathrm{Sr}$ isotope stratigraphy due to its rapid monotonous increase from 0.7082 to 0.7092 through geological time (Fig. 3), with age uncertainties of better than $\pm 1 \mathrm{Ma}$ (Elderfield, 1986; McKenzie et al., 1988; Hodell et al., 1991; McArthur et al., 2001).

\section{Sampling strategy and methods}

The most reliable material for $\mathrm{Sr}$ isotope dating is biogenic calcite, especially unaltered mollusc shells large enough to be physically separated from the surrounding rock (Elderfield, 1986). For this study, we have collected 31 samples from 15 different sites across the Zagros region. These samples were not obviously influenced by diagenesis and consisted mainly of macrofossils such as oysters and bivalves containing well preserved biogenic calcite that still exists in its original aragonitic or low $\mathrm{Mg}$ calcite form.

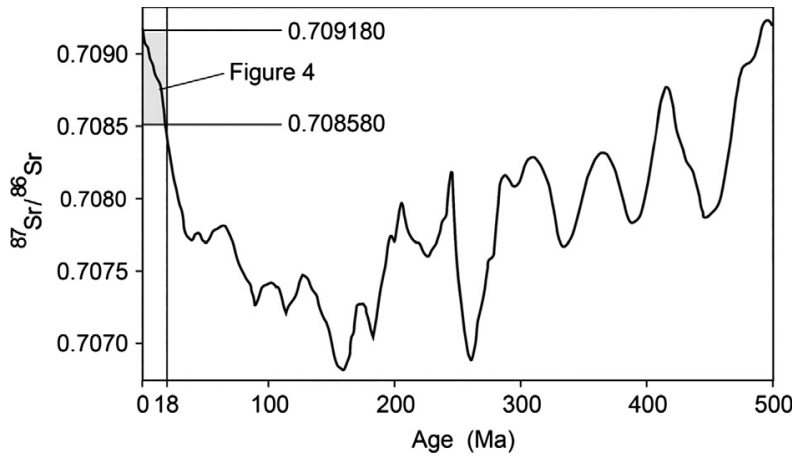

Fig. 3. Variation of ${ }^{87} \mathrm{Sr} /{ }^{86} \mathrm{Sr}$ in sea water through Phanerozoic time (modified from McArthur \& Howarth, 2004) along with determined age range of the Mishan foredeep deposits in the $\mathrm{Za}$ gros foreland basin.

About fifty milligrams of each sample was physically separated from the enclosing rocks using a binocular microscope. Samples were washed several times with deionized water using an ultrasonic machine. The prepared samples were dissolved in $1.8 \mathrm{~mL}$ of $2 \mathrm{M}$ acetic acid. The solution was then centrifuged and the supernatant was pipetted out, dried on a hot plate and converted to nitrate form for column chemistry. Sr was separated from the matrix using a $\mathrm{Sr}-\mathrm{spec}$ resin and was loaded onto a Re filament with a $\mathrm{TaO}$ activator. Strontium isotope measurements were done at the University of Geneva using the TRITON Thermo Finnigan Thermal Ionization Mass Spectrometer (TIMS). Isotope ratios were measured on Farady cups in static mode using the virtual amplifier mode to reduce uncertainty in the amplifier cross-calibration. The ${ }^{87} \mathrm{Sr} /{ }^{86} \mathrm{Sr}$ values were internally corrected for fractionation using a ${ }^{88} \mathrm{Sr} /{ }^{86} \mathrm{Sr}$ value of 8.375209 . All strontium ratios presented in this paper were subsequently normalized offline to the value of the SRM987 standard $\left({ }^{87} \mathrm{Sr} /{ }^{86} \mathrm{Sr}=0.710248\right)$ by applying a $+0.03 \%$ per amu correction factor based on more than 100 measurements of the SRM987 standard. The long-term $(>100$ measurements) external reproducibility $(1 \sigma)$ of the SRM987 standard is $<7 \mathrm{ppm}$. The numerical ages of the samples were determined by plotting the measured ${ }^{87} \mathrm{Sr} /{ }^{86} \mathrm{Sr}$ values on the ${ }^{87} \mathrm{Sr} /{ }^{86} \mathrm{Sr}$ LOWESS (LOcally WEighted Scatterplot Smoothing) curve (Fig. 4) calibrated by McArthur et al. (2001). These ages represent the maximum ages of the fossils and they correspond to depositional ages of sediments if no reworking has taken place. The LOWESS best-fit curve gives robust statistical uncertainties on any measured age (McArthur et al., 2001; McArthur \& Howarth, 2004). The uncertainty of ages in this paper includes uncertainty of the $\mathrm{Sr}$ global seawater curve, measurements, tools and any isotopic heterogeneity. The strontium isotope values of 31 samples (A.1) are categorized into three distinctive groups and explained in the next section on the basis of the geological provinces within which they occur. 


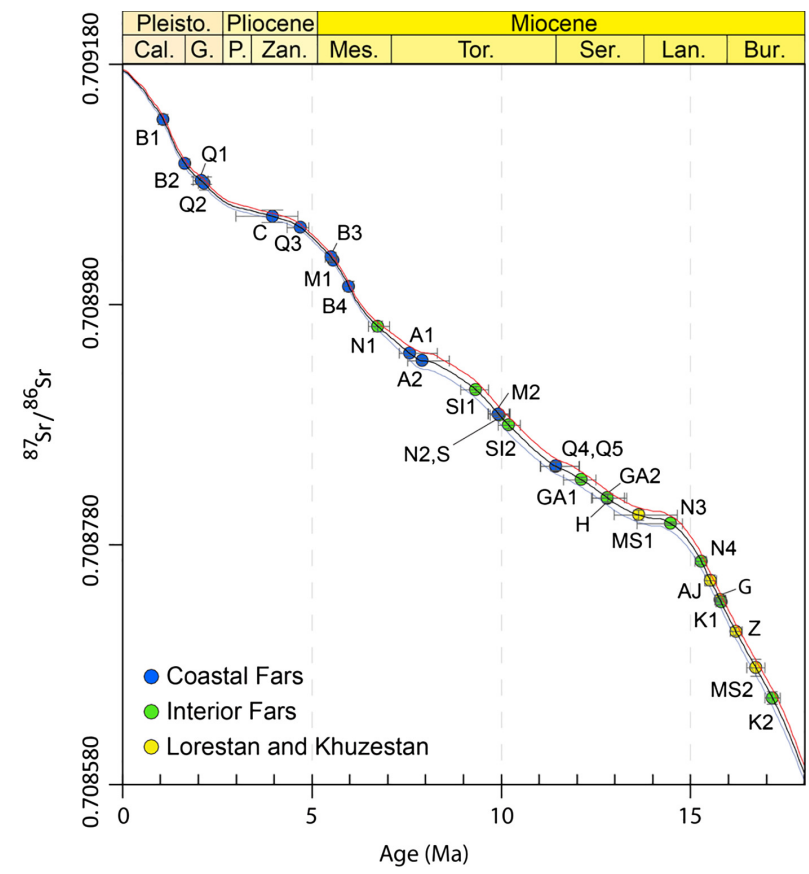

Fig. 4. Plot of the Sr isotope age results of the marine foredeep deposits (Mishan Formation) on the LOWESS curve (McArthur et al., 2001). Abbreviations are defined as follows (see also Fig. 5a): A, Asaluyeh; AJ, Agha Jari; B, Bostaneh; C, Charak; G, Gatvand; GA, Gach; H, Haftkel; K, Kaftar; M, Mand; MS, Masjed Solayman; N, Nakh; Q, Qeshm; S, Sepidar; SI, Siah; Z, Zarinabad.

\section{AGE RESULTS OF MARINE FOREDEEP DEPOSITS}

\section{Western sector}

In the western Zagros, six samples were analyzed from five sections (Zarinabad, Gatvand, Masjed Solayman, Haftkel and Agha Jari anticlines) in the southern part of the western sector (Lorestan and Khuzestan provinces) (Fig. 5a). The maximum absolute ages of the marine deposits are $16.7 \pm 0.2 \mathrm{Ma}$ at the base and $12.8 \pm 0.5 \mathrm{Ma}$ at the top in the southern part of the Mountain Frontal Fault in the western sector of the $\mathrm{Za}$ gros region (Figs 4 and 5).

\section{Eastern sector}

In the eastern Zagros mountain belt, 10 sections were considered for $\mathrm{Sr}$ isotope dating (Fig. 5a). A total of 25 fossils were collected along the measured sections and outcrops of the Neogene deposits in the Simply Folded Belt. Results show that the marine deposits have a wide range of ${ }^{87} \mathrm{Sr} /{ }^{86} \mathrm{Sr}$, which indicates a long temporal duration for the marine basin in the Fars region. The oldest measured $\mathrm{Sr}$ age of the Mishan Formation is $17.2 \pm 0.2 \mathrm{Ma}$ in the Zagros simply folded belt, while an age of $1.1 \pm 0.1 \mathrm{Ma}$ was obtained in the uppermost preserved unit in the distal part of the simply folded belt next to the modern coast of the Persian Gulf (Figs 4 and 5).
The thick marine deposits in the Fars were deposited in a relatively deep basin compared with the Lorestan and Khuzestan regions and were possibly less affected by continental input (Pirouz, 2013). The results of the Fars region are divided into two sectors: Interior and Coastal Fars, which are explained in the next sections.

\section{Interior Fars}

The middle part of the Zagros basin in the Fars region is considered for Sr dating in five sections (Sepidar, Kaftar, Gach, Siah and Nakh anticlines) (Fig. 5a). A total of 11 fossils were sampled in our field studies. The maximum age of the marine foredeep is $17.2 \pm 0.2 \mathrm{Ma}$, while the youngest marine deposits have an age of $6.7 \pm 0.3 \mathrm{Ma}$ (Figs 4 and 5).

\section{Coastal Fars}

Strontium dating analysis has been carried out on 14 samples from five sections (Asaluyeh, Mand, Charak, Bostaneh and Qeshm anticlines) in the distal part of the Zagros simply folded belt next to the modern coast of the Persian Gulf (Fig. 5a). The Neogene succession above the Gachsaran Formation is mostly marine in the Coastal Fars region. The oldest sample of marine material has an age of $11.5 \pm 0.5 \mathrm{Ma}$ while the uppermost unit has an age of $1.1 \pm 0.1 \mathrm{Ma}$ (Figs 4 and 5 ).

\section{DISCUSSION}

\section{Age of the Zagros marine foredeep}

Based on the $\mathrm{Sr}$ isotope ages, previous palaeomagnetic studies (Homke et al., 2004; Emami, 2008; Khadivi et al., 2010) and the thickness of preserved foredeep deposits, we have calculated net deposition rates for the Mishan Formation at individual sections. The net average deposition rate is about $0.1 \pm 0.02 \mathrm{~mm}$ year $^{-1}$. These calculations enabled us to estimate the ages of the upper and lower stratigraphic contacts for the Mishan marine deposits under the assumption that the depositional rates are constant in time (Fig. 5b). These estimates are of interest because they enable us to roughly evaluate at a regional scale the time at which deposition in the basin changed from continental to marine conditions (in the case of the lower contact) or marine to continental conditions (for the upper contact).

This analysis shows that the western part of the Zagros foreland basin (Lorestan and Khuzestan regions) records a shallow marine foredeep between $c a$. 16.5 and 14.2 Ma, while in the southern portion of the Khuzestan (Dezful embayment) the marine foredeep occurs between $c a .17$ and $12 \mathrm{Ma}$ (Fig. 5b). The passage from a marine to a non-marine environment occurred in the Late Langhian (ca. 14.2 Ma) in the north and in the Serravallian (ca. $12 \mathrm{Ma}$ ) in the south western part of the Zagros basin. We consider these times to roughly indicate when 
(a)

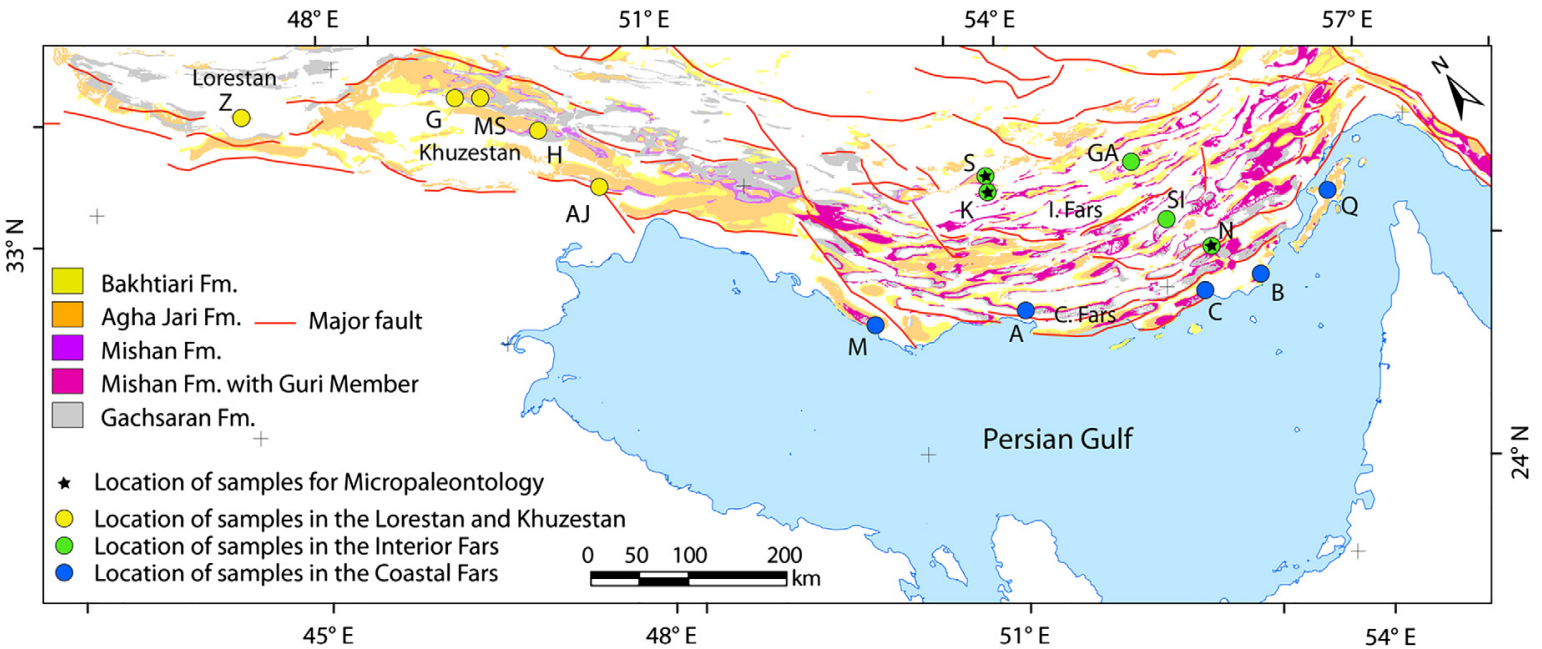

(b) $\mathrm{W}$

E N
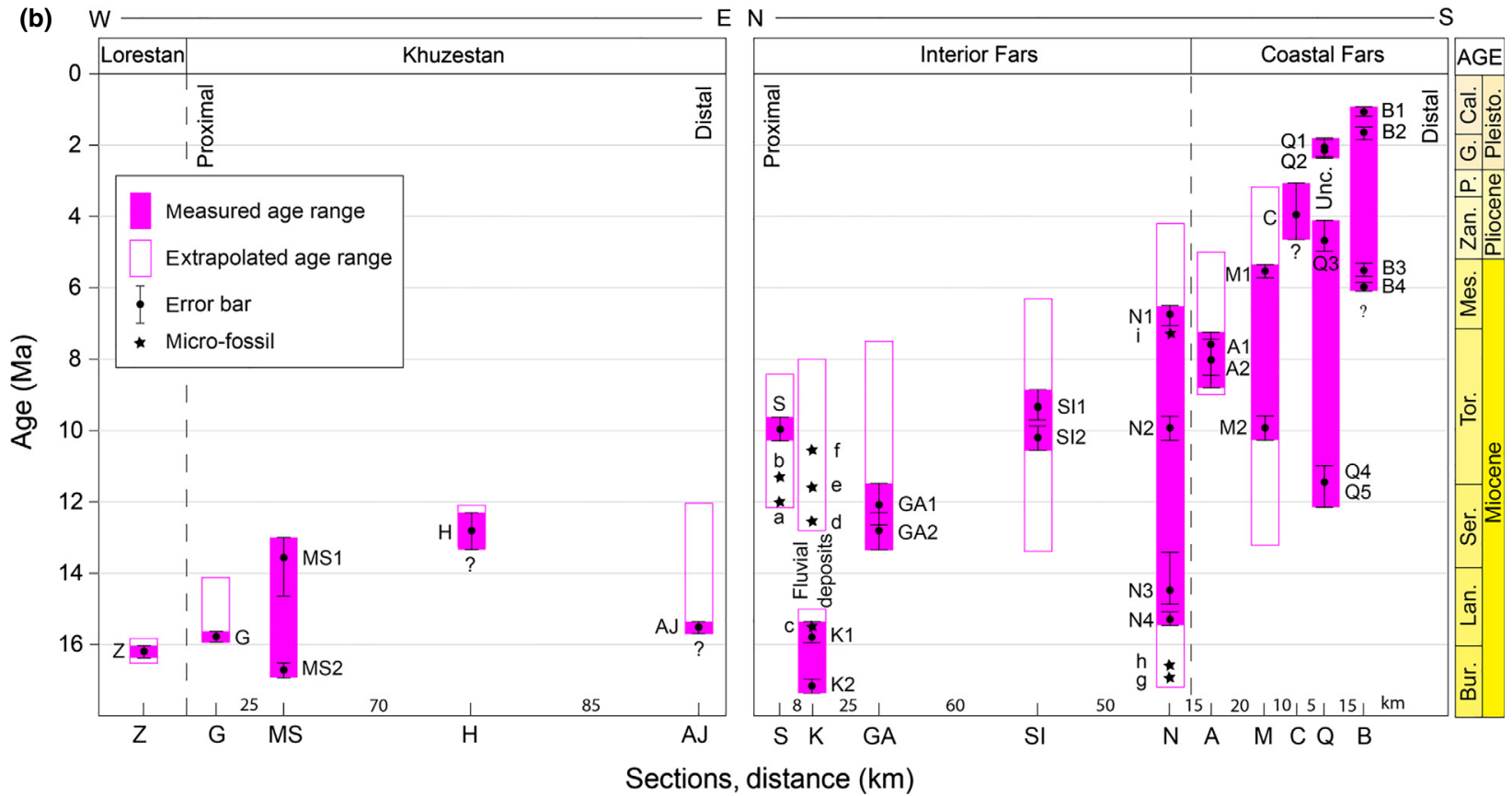

Fig. 5. (a) Map showing locations of samples analyzed for strontium isotope dating and micropalaeontology (star) across the Zagros region. (b) Distribution of the Sr isotope results of the marine foredeep deposits (Mishan Formation) within the Zagros region. Absolute age ranges of the Mishan are shown with pink filled quadrants, extrapolated age range is shown with open quadrants (calculated based upon Sr dating results and net deposition rate), and error bars are indicated in black. Fossils (star) are Archaias sp. (a), Operculina complanata (b), Spherogypsina sp. (c), Borelis pygmaea (d), Bigenerina sp. (e), Amphistegina lesson (f), Miogypsina cf. globulina (g), Archaias sp. (h), and Tubucellaria sp. (i). Question marks in Figure (b) imply that the base of the Mishan foredeep deposits has no outcrop. Abbreviations are defined as follows: Cal., Calabrian; G., Gelasian; P., Piacenzian; Zan., Zanclean; Mes., Messinian; Tor., Tortonian; Ser., Serravallian; Lan., Langhian; Bur., Burdigalian; A, Asaluyeh; AJ, Agha Jari; B, Bostaneh; C, Charak; G, Gatvand; GA, Gach; H, Haftkel; K, Kaftar; M, Mand; MS, Masjed Solayman; N, Nakh; Q, Qeshm; S, Sepidar; SI, Siah; Z, Zarinabad.

different parts of the basin became overfilled. It is worth noting that magnetostratigraphic investigations indicate that the deposition of continental sediments started not later than $c a .12 .8 \mathrm{Ma}$ in the Zarinabad and $c a .12 .3 \mathrm{Ma}$ in the Changuleh (Fig. 1) in the extreme western sector (Lorestan region) (Homke et al., 2004), which match well with our results.

The eastern part of the Zagros foreland basin (Fars) records a shallow marine foredeep between $c a$. 18-15 Ma and $c a$. 13-8 Ma in the Interior Fars (Fig. 5b), separated by a fluvial sedimentary environment between the
Langhian and Serravallian (ca. 15-13 Ma). These results also imply that the underlying Razak fluvial sedimentary environment (Fig. 2) occurred in the Burdigalian, which is comparable with results of magnetostratigraphy (Khadivi et al., 2010) obtained from the Razak Formation in the northern part of the Interior Fars (Chahar Makan). Towards the south in the Nakh section, the Mishan Formation shows a longer time duration between the Burdigalian and Messinian (ca. 17-4.2 Ma). Towards the south in the Coastal Fars region, the oldest outcrop has an age of $c a$. 11.5, whereas the base of the Mishan Formation 


\section{Pirouz et al.}

is located at a depth of $-350 \mathrm{~m}$ below the sea level and has an extrapolated age of $c a$. 14.7 Ma. The top of the Mishan Formation has an age of $c a$. 1.5 Ma (in the Bostaneh anticline) next to the modern coast of the Persian Gulf (Fig. 5b).

In general, during the Langhian ( $c a .17-15 \mathrm{Ma}$ ), the very shallow marine environment (lagoon and restricted environments) of the Mishan Formation extended to the north and covered the initial wedge top basin (Razak Formation) deposits in the eastern (Fars) part of the basin, while supratidal and sabkha deposits accumulated in the western (Dezful) part of the basin (Pirouz, 2013). Later on, the $\mathrm{MN}_{\mathrm{R}}$ (Guri Member) and $\mathrm{MN}_{\mathrm{M}}$ lithofacies associations are well developed in the western sector and are relatively older in the north (between $c a .13$ and $9 \mathrm{Ma}$ ), becoming younger (between $c a .12$ and $1 \mathrm{Ma}$ ) in the more distal part of the basin in Coastal Fars region (Fig. 5b).
Based upon our new results and magnetostratigraphic data from the Razak, Agha Jari and Bakhtiari fluvial deposits (Homke et al., 2004; Emami, 2008; Khadivi et al., 2010) along with $\mathrm{Sr}$ results for the Asmari (Ehrenberg et al., 2007; van Buchem et al., 2010), we have established a new chronostratigraphic chart for the Neogene part of the Zagros foreland basin (Fig. 6). This chart differs significantly from the pre-existing diagram in that the Mishan, Agha Jari and Bakhtiari Formations are all strongly diachronous across the basin. In addition, the upper limit of the Asmari Formation (the age for the base of the foreland basin) is moved back in time.

\section{Migration rates of the Zagros foredeep}

Our results also enable us to provide new constraints on foredeep migration rates across the Zagros basin (Table 1

(a)

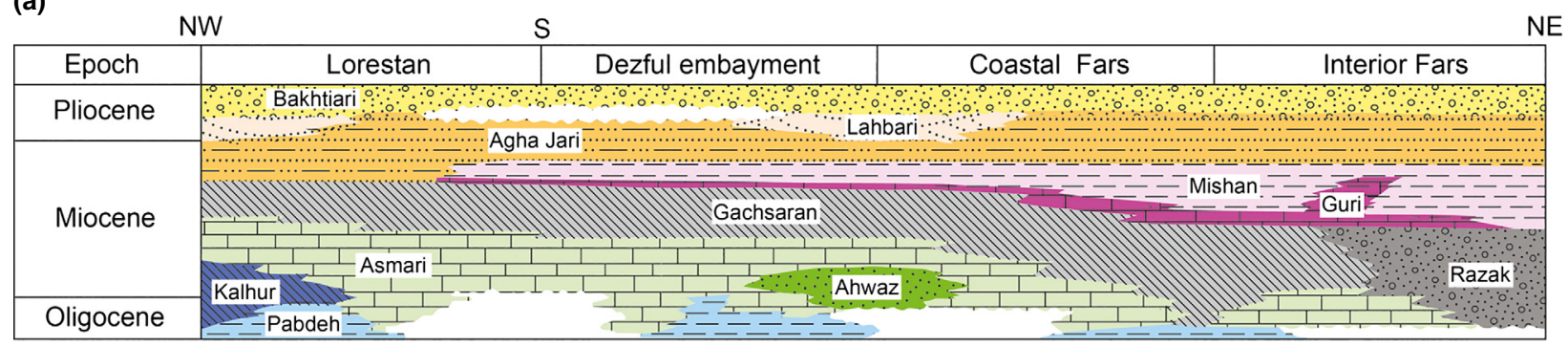

(b)

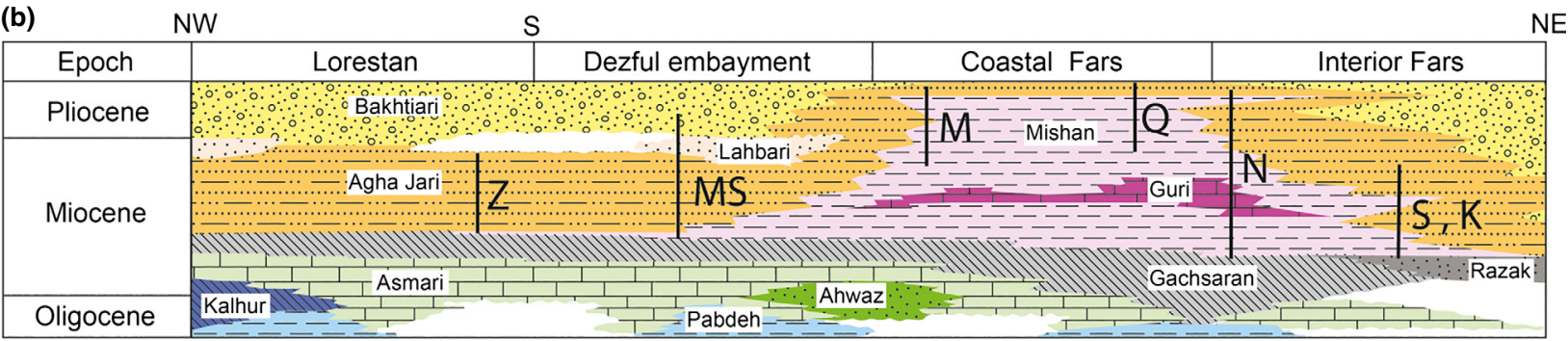

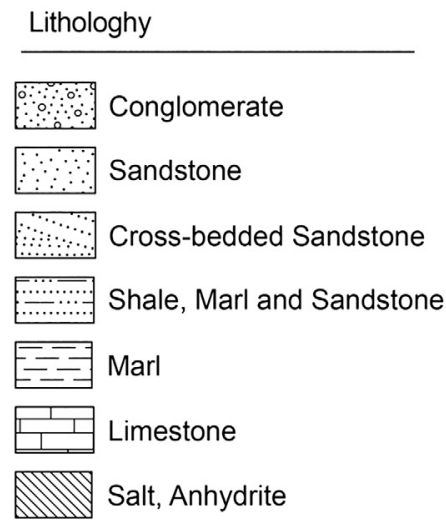

Foreland basin deposits
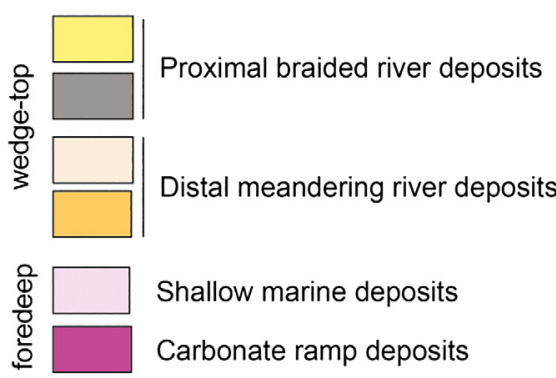

Shallow marine deposits

Carbonate ramp deposits

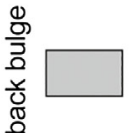

Supratidal and sabkha deposits
Older platform deposits

Carbonate platform deposits

$\square$ Delta deposits

Supratidal deposits

Deep marine deposits

Fig. 6. Pre-existing (a) and newly revised (b) chronostratigraphic charts of the Zagros foreland basin. The old chart is from James \& Wynd (1965). The new chart is based on our new Sr data result along with Sr results for the Asmari (Ehrenberg et al., 2007; van Buchem et al., 2010) and magnetostratigraphic data of the Razak, Agha Jari and Bakhtiari fluvial deposits (Homke et al., 2004; Emami, 2008; Khadivi et al., 2010). Abbreviations are defined as follows: K, Kaftar; M, Mand; MS, Masjed Solayman; N, Nakh; Q, Qeshm; S, Sepidar; Z, Zarinabad. 
Table 1. Calculated propagation rates for the Neogene Zagros foreland basin

\begin{tabular}{|c|c|c|c|}
\hline Sector & $\mathrm{T}(\mathrm{Ma})$ & $\mathrm{P}\left(\mathrm{km} \mathrm{Ma}^{-1}\right)$ & Source \\
\hline \multicolumn{4}{|c|}{ Eastern Zagros } \\
\hline & $4.2-1$ & 18.75 & \multirow{4}{*}{ This study } \\
\hline & $8.2-4.2$ & 32.5 & \\
\hline & $11.5-8.2$ & 0 to $>32$ & \\
\hline & $13.5-11.5$ & 0 & \\
\hline & $16-13.5$ & 24 & \multirow{2}{*}{$\begin{array}{l}\text { Khadivi } \text { et al. (2010); } \\
\text { Pirouz (2013) }\end{array}$} \\
\hline & $18-16$ & 20 & \\
\hline \multicolumn{4}{|c|}{ Western Zagros } \\
\hline & $9-0$ & $>10$ to $<20$ & \multirow{3}{*}{ This study } \\
\hline & $12-9$ & $<10$ & \\
\hline & $12.5-12$ & 52 & \\
\hline & $14.5-12.5$ & 0 to $<10$ & \multirow[t]{2}{*}{ Pirouz (2013) } \\
\hline & $16-14.4$ & 0 & \\
\hline
\end{tabular}

and Fig. 7). The $\mathrm{Sr}$ ages for the uppermost part of the Mishan Formation show that the marine foredeep was completely filled in the northern part of the Interior Fars around ca. $8.4 \mathrm{Ma}$ (Sepidar and Gach anticlines) and ca. 4.2 Ma in the southern Interior Fars (Nakh anticline) (Fig. 5). Based on the present-day distance obtained from restored structural and seismic cross-sections (Jahani et al., 2009) between those two outcrops, approximately $136 \mathrm{~km}$ of southward foredeep migration occurred in $4.2 \mathrm{Ma}$ (between 8.4 and $4.2 \mathrm{Ma}$ ) with a rate of $32.4 \mathrm{~mm}_{\text {year }}{ }^{-1}$. In comparison, the distance between the Nakh anticline and the Persian Gulf coast, which is where the modern foredeep is found, is less than $60 \mathrm{~km}$ (Fig. 5). Therefore, here the migration occurred between 4.2 and $1 \mathrm{Ma}$ with a rate of $18.7 \mathrm{~mm} \mathrm{year}^{-1}$. In the western part of the Zagros basin, the Neogene deposits record approximately $185 \mathrm{~km}$ of southeastward foredeep migration using interpreted seismic lines (Sherkati \& Letouzey, 2004) within 2 million years, which implies an along strike migration rate of $92.5 \mathrm{~mm}$ year ${ }^{-1}$ and an orogen-perpendicular migration rate of $56.5 \mathrm{~mm} \mathrm{year}^{-1}$ in the Late
Serravallian (ca. $12 \mathrm{Ma}), 18.5 \mathrm{~mm} \mathrm{year}^{-1}$ in the Early Serravallian (ca. $13 \mathrm{Ma}$ ) and less than $10 \mathrm{~mm} \mathrm{year}^{-1}$ in the Late Langhian (ca. $14 \mathrm{Ma}$ ). These results show that the migration rate of the Mishan foredeep depocentre was 2.5 times faster during the Serravallian in the western sector and two times faster during the Tortonian and Messinian in the eastern sector compared with the Zanclean to present.

The western sector of the Zagros foreland basin became overfilled (Pirouz, 2013) after 12 Ma after which no marker is available to calculate the rate of propagation in detail. Nevertheless, the overall minimum propagation rate is about $20 \mathrm{~mm} \mathrm{year}^{-1}$ in the western sector during the last $12 \mathrm{Ma}$ on the basis of the available data.

The foreland basin migration rates calculated here for the Zagros (between 50 and $17.8 \mathrm{~mm} \mathrm{year}^{-1}$ ) are among the highest for any pro-foreland basin in the world (Fig. 7). However, this migration rate is a function of convergence rate, flexural rigidity, sediment supply and accommodation space as discussed previously and differs from one to another foreland. For instance, the basin migration rates are about $5-10 \mathrm{~mm} \mathrm{year}^{-1}$ in the Apennines (Ricci Lucchi, 1986), between 5 and $12.9 \mathrm{~mm} \mathrm{year}^{-1}$ in the Alps (Sinclair, 1997b), about $10 \mathrm{~mm}$ year $^{-1}$ in the southern Pyrenees (Vergés et al., 2002), between 4 and $48 \mathrm{~mm} \mathrm{year}^{-1}$ in the Andes retroforeland in Argentina (DeCelles et al., 2011), and $15 \mathrm{~mm}$ year $^{-1}$ in the Ganges basin in Himalaya (Mugnier \& Huyghe, 2006).

\section{Controls on rates of foredeep migration}

What caused the Zagros foredeep to migrate in the manner outlined in the previous section? The stratigraphic architecture of a foreland basin may be influenced by a variety of factors, notably eustatic sea level variations (Catuneanu, 2002; Miller et al., 2005), sediment supply and the creation of accommodation space (Allen et al., 2013; Ballato \& Strecker, 2014), which itself depends on

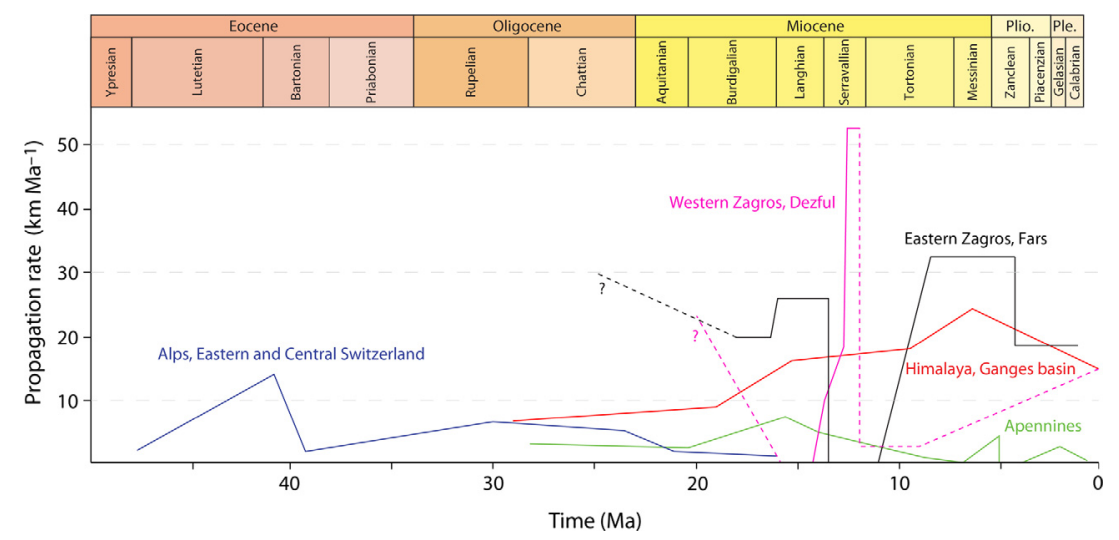

Fig. 7. Foreland basin propagation rates (perpendicular to the orogen) for different basins along the Alpine-Himalayan system. The propagation rate of the western Zagros is shown in pink. Dashed line represents a rough estimate based upon our results and previous palaeomagnetostatigraphy and biostratigraphy studies (Homke et al., 2004; Emami, 2008; Fakhari et al., 2008). The propagation rate for the eastern Zagros is shown in black (this study), the Alps in blue (Sinclair et al., 1991; von Hagke et al., 2012), Apennines in green (Ricci Lucchi, 1986), Himalaya in red (Mugnier \& Huyghe, 2006). 
the distribution of deformation in the orogen (Ricci Lucchi, 1986) and the flexural rigidity of the foreland lithosphere (Allen \& Allen, 2005). Changes in any one of these factors may drive regression or transgression of the coastline, causing the adjacent depositional environments to migrate laterally.

For example, an abrupt climate-driven increase in sediment flux into the basin is expected to trigger a coastal regression, without any advancement of deformation in the orogen (Ballato \& Strecker, 2014). On the other hand, thrust-load emplacement in the deforming mountain belt may drive flexural subsidence in the foredeep, causing transgression to occur. At the same time, this may lead to higher topographic relief, steeper slopes, faster erosion and greater supply of sediment to the basin, which may be manifest by progradation of a coarse clastic wedge into the basin. The possibilities for complicated interactions involving feedback are numerous, making it challenging to understand with any certainty controls on variations in foreland basin architecture.

Despite these complications, it is clear that the Zagros foreland basin migrates roughly towards to southwest through time, as does the deformation front. This correspondence suggests to us that the advancement of the $\mathrm{Za}-$ gros orogen (i.e. the deformation front) plays a first order control on migration of the foredeep basin. In this section, we test whether widening of the deforming mountain belt can explain the observed (orthogonal) foredeep propagation rates observed in the Zagros.

Assuming an orogen has a gross triangular geometry and that it enlarges in response to frontal accretion of sediments from an incoming plate undergoing no erosion, Dahlen (1990) showed that the wedge width grows according to:

$$
W=\left(\frac{\sqrt{2 h v t}}{\tan (\alpha+\beta)}\right)^{1 / 2}
$$

where $m$ is the width of the orogen $(\mathrm{m}), h$ is the thickness of sediments on the incoming plate $(\mathrm{m})$ moving at speed $v\left(\mathrm{~m} \mathrm{~s}^{-1}\right)$ relative to the wedge backstop, $t$ is the time (s) since accretion began, $\alpha$ is the surface slope of the wedge and $\beta$ is the slope of the detachment dipping towards the mountain belt. The rate at which the wedge widens (that we associate with the rate at which the foredeep migrates) can be obtained by differentiating (1) with respect to time to yield:

$$
\frac{\partial w}{\partial t}=\frac{h v}{\sqrt{\frac{2 h v t}{\tan (\alpha+\beta)}} \tan (\alpha+\beta)} .
$$

Figure 8 shows $w$ and $\partial w / \partial t$ computed from Eqn (2) vs. time (dash line) for parameter values relevant to the Zagros $[h=8 \mathrm{~km}$ from the basal Hormuz salt to the Oligo-Miocene Asmari Formation (Morris, 1977; Alavi, 2004, 2007), $v=20 \mathrm{~km} \mathrm{Ma}^{-1}$ (Reilinger et al., 2006),
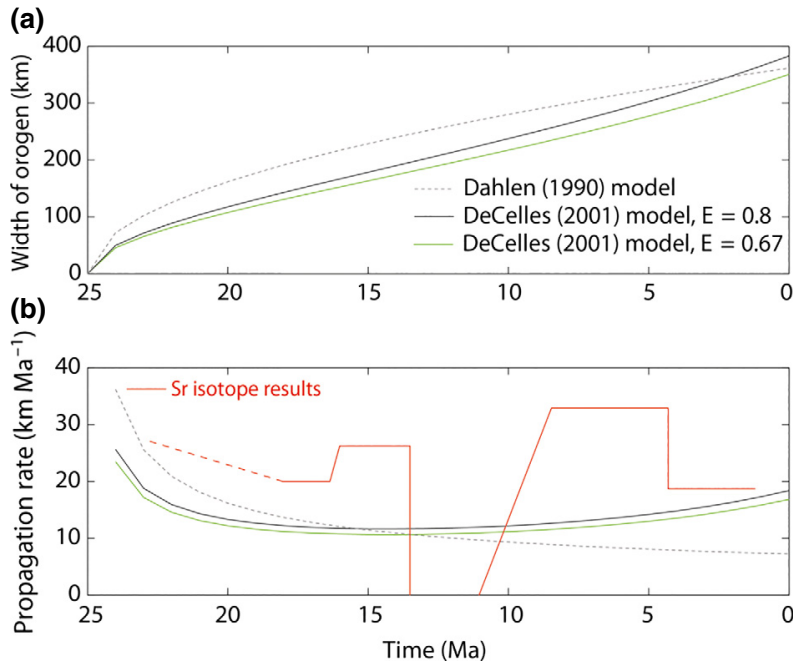

Fig. 8. Wedge widening (a) and rate of widening (deformation front propagation rate) (b) as a function of time, predicted by two different models: Dahlen (1990), dashed line, and DeCelles $\&$ DeCelles (2001), green line for $E=0.67$ and black line for $E=0.8$. The equations are defined in the main text. Also shown are our estimates for the Zagros obtained from $\mathrm{Sr}$ isotope stratigraphy (red line).

$\alpha=2^{\circ}, \beta=2.5-3^{\circ}$ (Snyder \& Barazangi, 1986; Paul et al., 2010)]. The timing of collision is not well constrained but took place no later than about $20 \mathrm{Ma}$ (Khadivi et al., 2010; Ballato et al., 2011; Mouthereau, 2011; McQuarrie \& van Hinsbergen, 2013), which is when the first clear signs of clastic deposition occurred in the northern part of the Zagros (represented by the Razak formation) (Khadivi et al., 2010). One sees that high propagation rates of $c a .40 \mathrm{~mm}$ year $^{-1}$ are possible within the first few million years following collision, but these rates decrease rapidly and are anticipated to be no more that $c a .10 \mathrm{~mm} \mathrm{year}^{-1}$ after $10 \mathrm{My}$. After $20 \mathrm{Ma}$, the orogen would have a total width of $338 \mathrm{~km}$, which is similar to the width of the Zagros in the Fars regions today.

DeCelles \& DeCelles (2001) showed that the variation in the wedge dip (i.e. $\beta$ ) through time can have a large influence on wedge propagation rates. Assuming that $\beta$ decreases linearly with time, these authors showed that the propagation rate initially decreases, as with the Dahlen model, whereas after a certain time it begins to increase. This acceleration takes place because as the wedge taper decreases, there is progressively less area in the orogen to accommodate mass accreted at the deformation front, causing it to widen more rapidly. We have used the DeCelles \& DeCelles (2001) model to test whether it can explain the variations in the propagation rates observed in the Zagros. In this model, the orogen width $(w)$ and orogen propagation rate $(\partial m / \partial t)$ are computed according to:

$m=\left|\frac{\beta_{0}\left(|B|+x_{0}^{2}\right)}{|K|\left(\frac{\alpha}{|K|}-t\right)}-\right| B||^{1 / 2}$, 
$\frac{\partial w}{\partial t}=\frac{|K|}{2 x \beta_{0}} \cdot\left[\frac{\left(|B|+x^{2}\right)^{2}}{|B|+x_{0}^{2}}\right]$

Where

$B=\frac{(2 v h E)}{K}$

$K=\frac{\left(\beta_{f}-\beta_{0}\right)}{t_{f}-t_{0}}$

$E$ is the fraction of rock that survives erosion to build the wedge (varying between 0 and 1), $\beta_{0}$ and $\beta_{f}$ are the initial and final slopes of the detachment dipping towards the mountain belt at times $t_{0}$ and $t_{f}, t$ is the time (s), $v$ is velocity $\left(\mathrm{m} \mathrm{s}^{-1}\right)$ of foreland subduction, $h$ is the thickness (m) of sediments on the incoming plate, $M_{0}$ is the preexisting mass of the wedge and $x_{0}$ is the initial wedge width (DeCelles \& DeCelles, 2001). The erosion parameter $E$ can be calculated from the following relation:

$E=\frac{\left(\frac{x^{2} \beta_{f}}{2}-M_{0}\right)}{v h t_{f}}$

In Fig. 8 we plot the results of Eqns (3) and (4) using parameter values estimated for the Zagros. Using $x=350 \mathrm{~km}, \beta_{f}=2.5-3^{\circ}$ (Snyder \& Barazangi, 1986; Paul et al., 2010), $v=20 \mathrm{~km} \mathrm{Ma}^{-1}$ (Reilinger et al., 2006), $h=8 \mathrm{~km}$ (Morris, 1977; Alavi, 2004, 2007), $t_{f}=25 \mathrm{Ma}$ (Khadivi et al., 2010; Ballato et al., 2011; Mouthereau, 2011; McQuarrie \& van Hinsbergen, 2013) and $M_{0}=0$ assuming all of the mass of the wedge is due to thrusting yields $E \cong 0.67-0.80$ from Eqn (5). This implies that more than two thirds of the mass going into the Zagros wedge survives erosion to build up topography. The plot (green line for $E=0.67$ and black line for $E=0.8)$ predicts that $\partial w / \partial t$ decreased rapidly during the first $10 \mathrm{Ma}$ of shortening in the Zagros. This rate has been constant at about $10.5-11.5 \mathrm{~km} \mathrm{Ma}^{-1}$ between 15 and $10 \mathrm{Ma}$, but the curves suggest that since the Zagros fold-thrust belt reached a width of ca. 160-180 km (depending on the actual change in $\beta$ ) the propagation rate has accelerated up to $17-18.5 \mathrm{~km} \mathrm{Ma}^{-1}$.

Comparison with propagation rates based on $\mathrm{Sr}$ isotope stratigraphy (Fig. 8b) (red curve) shows that although the simple models can match observed rates immediately following collision, they fail to explain elevated propagation rates $\left(c a .33 \mathrm{~mm} \mathrm{year}^{-1}\right)$ between 11 and $8 \mathrm{Ma}$.

We suspect the main reason for the inability of the simple wedge model to explain foreland basin propagation rates in the Zagros is due to migration of deformation front beneath the active foredeep i.e. basement faulting. It is worth noting that number of other studies have proposed involvement of the basement faults in the deformation (Blanc et al., 2003; Sherkati \& Letouzey, 2004; Molinaro et al., 2005; Sepehr \& Cosgrove, 2005; Mouthereau et al., 2007; Emami et al., 2010; Vergés et al., 2011). Although there is no clear seismic image of the Zagros basement in the eastern sector due to the Hormuz salt, fault plane solutions of the large earthquakes with hypocenters located below the salt (Jackson, 1980) indicate high angle reverse faulting (40-50) on a large number of faults across the entire width of the Zagros belt (Fig. 9) (Jackson, 1980; Snyder \& Barazangi, 1986; Talebian \& Jackson, 2004). This reverse faulting is probably occurring by reactivation of old normal faults formed originally during Permo-Triassic extension (Jackson, 1980).

We suggest that the rapid migration rate (33 $\mathrm{mm} \mathrm{year}^{-1}$ ) during Late Miocene presents the time when sub-wedge deformation jumped forward from the Mountain Frontal Fault to the Zagros Foredeep Fault in the south (Fig. 10). This would have uplifted large parts of the previous foredeep basin while generating new subsidence in the footwall far south of the previous foredeep,

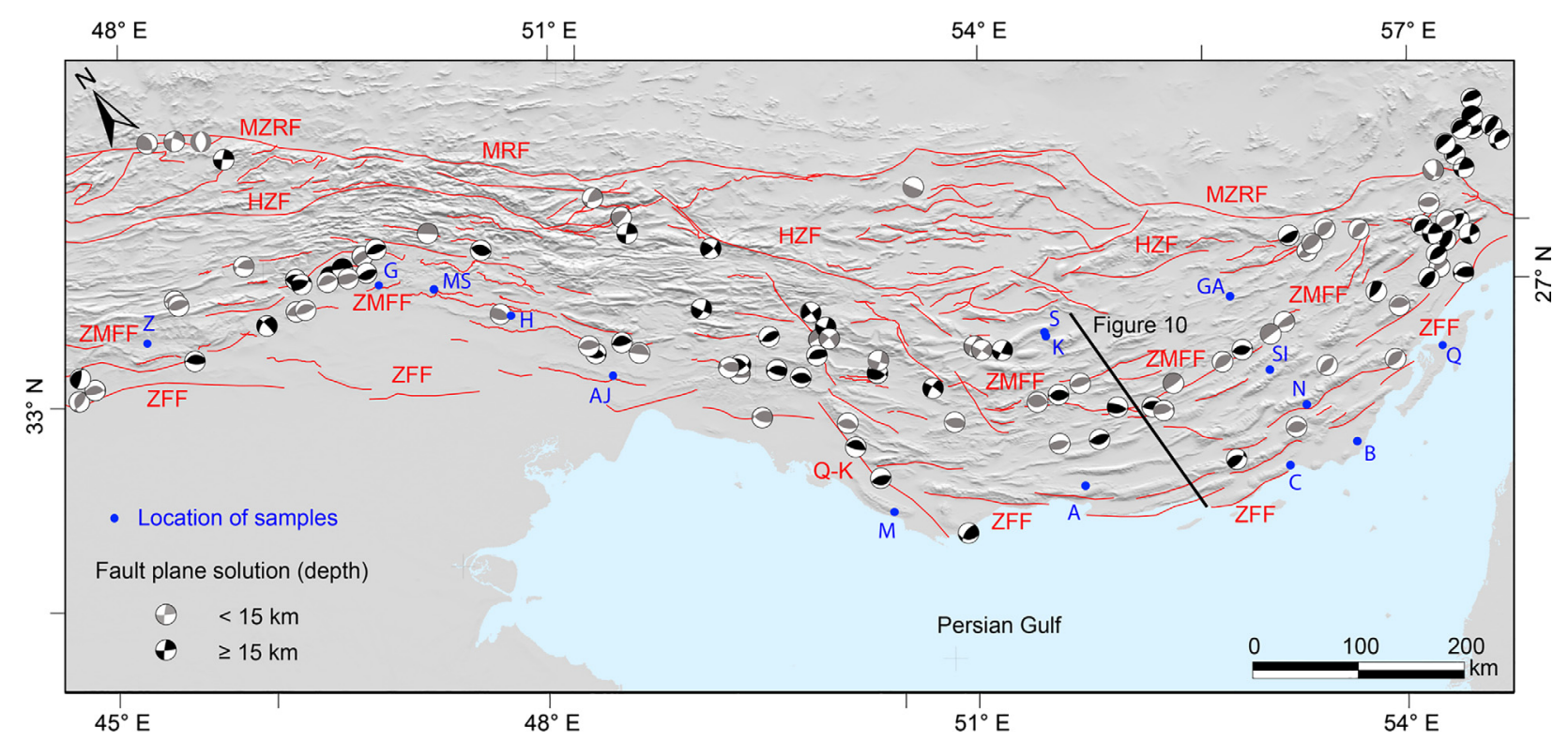

Fig. 9. Summary of fault plane solutions in the Zagros Fold-Thrust belt (modified from Talebian \& Jackson, 2004; Jackson, 1980). 

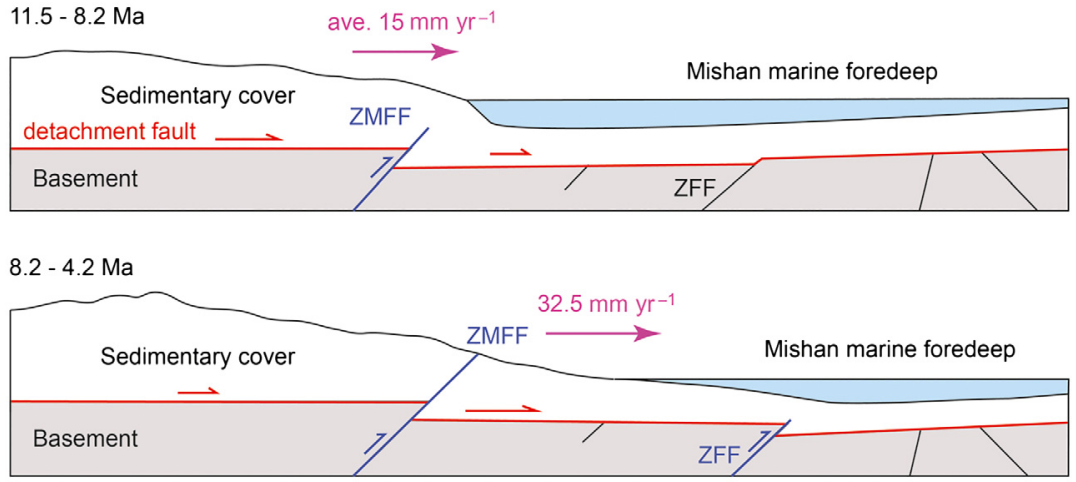

4.2 - $1 \mathrm{Ma}$

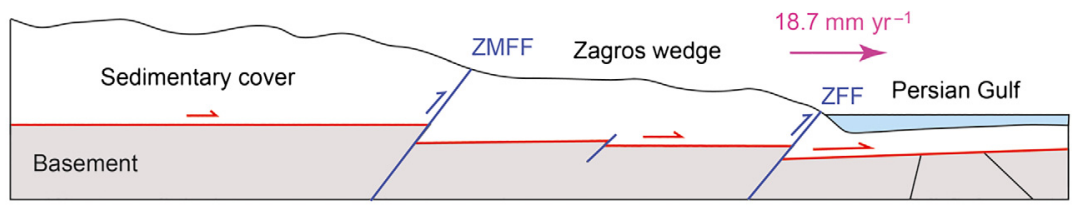

Horizontal scale: $\stackrel{25 \mathrm{~km}}{\longmapsto}$
Fig. 10. Schematic view of the eastern Zagros (Fars) since the Middle Miocene. Reactivation of major basement faults leads to abrupt periods when the foredeep migrates rapidly southwards. The location of the schematic section is shown on the Fig. 9. Length of arrows indicates relative movement on the fault planes. leading to a large apparent foredeep propagation rate. This suggestion is consistent with Khadivi et al. (2012) who identified late Miocene uplift on the basis of appetite fission track thermal modelling and Hessami et al. (2001) who showed that the Zagros deformation front coincided with the Mountain Frontal Fault in the Early Miocene and the Zagros Foredeep Fault in the Late Miocene on the basis of unconformities. In addition, our interpretation is in good agreement with other studies that show faster folding occurred after $12 \mathrm{Ma}$ (Khadivi et al., 2010) and slowing down of Arabia-Eurasia convergence ca. $30 \%$ from $c a .5 \mathrm{Ma}$ to the present day (Austermann \& Iaffaldano, 2013).

\section{CONCLUSIONS}

On the basis of our new $\mathrm{Sr}$ isotope stratigraphy results, we have shown that the marine foredeep in the Zagros foreland basin (represented by the Mishan Formation) has a wide age range and shows prominent diachronous characteristics. The marine deposits are oldest in northwest $(c a .17 \mathrm{Ma})$ and become gradually younger towards the southeast ( $c a .1 \mathrm{Ma}$ ). The western part of the Zagros basin became overfilled at about $c a .12 \mathrm{Ma}$ and the main depocentre migrated towards the southeast. In the eastern sector (northern Interior Fars) the basin became overfilled at ca. $8.4 \mathrm{Ma}$, while this occurred at ca. 4.2 $\mathrm{Ma}$ in the southern Interior Fars. These new age constraints demonstrate that the Zagros foredeep basin migrated rapidly towards the southwest during the Neogene at rates of between about 10 and $50 \mathrm{~mm}$ year $^{-1}$, with rates two times faster in the past (Miocene) compared with the Pliocene. These foredeep migration rates are not easily explained by progressive widening of a critical wedge growing by frontal accretion. Rather periods of rapid foredeep migration appear to be controlled by reactivation of major widely spaced basement faults. This has resulted in periods during which the foredeep stepped abruptly forward leading to high apparent foredeep propagation rates exceeding those measured in any other foreland basin worldwide. Our study highlights the major role played by basement faults in the Zagros in controlling sedimentation in the foreland basin - something that would not be expected on the basis of the surface geology that is dominated largely by thin-skinned style deformation.

\section{ACKNOWLEDGEMENTS}

This study was supported by the Swiss National Science Foundation (grants no. P2GEP2-148801 and 200021117582). We thank Michèle Senn for helping with sample preparation for Sr isotope analysis and Sébastien Castelltort for discussions. We thank Peter van der Beek, Paolo Ballato and Eduard Saura for their thorough review and highly appreciate comments and suggestions, which significantly contributed to improving the quality of the publication. This research paper is lovingly dedicated to my mother, Ashraf Sadeghi Panahi.

\section{REFERENCES}

Agard, P., Omrani, J., Jolivet, L. \& Mouthereau, F. (2005) Convergence history across Zagros (Iran): constraints from collisional and earlier deformation. Int. F. Earth Sci., 94, 401419.

ALAVI, M. (2004) Regional stratigraphy of the Zagros fold-thrust belt of Iran and its proforeland evolution. Am. F. Sci, 304 (1), $1-20$. 
Alavi, M. (2007) Structures of the Zagros fold-thrust belt in Iran. Am. F. Sci., 307 (9), 1064-1095.

Allen, P.A. \& Allen, J.R. (2005) Basin Analysis: Principles and Applications, 560 p. Blackwell Publishing, Oxford, England.

Allen, M.B. \& Armstrong, H.A. (2008) Arabia -Eurasia collision and the forcing of mid-Cenozoic global cooling. Palaeogeogr. Palaeoclimatol. Palaeoecol., 265 (1-2), 52-58.

Allen, P.A., Crampton, S.L. \& Sinclair, H.D. (1991) The inception and early evolution of the North Alpine Foreland Basin, Switzerland. Basin Res., 3 (3), 143-163.

Allen, P.A., Armitage, J.J., Carter, A., Duller, R.A., Michael, N.A., Sinclair, H.D., Whitchurch, A.L., WhitTAKer, A.C. \& Schlunegger, F. (2013) TheQsproblem: sediment volumetric balance of proximal foreland basin systems. Sedimentology, 60 (1), 102-130.

Austermann, J. \& Iaffaldano, G. (2013) The role of the Zagros orogeny in slowing down Arabia-Eurasia convergence since $\sim 5$ Ma. Tectonics, 32 (3), 351-363.

AvouAC, J.P. (2003) Mountain building, erosion, and the seismic cycle in the Nepal Himalaya. Adv. Geophys., 46, 1-80.

Ballato, P. \& Strecker, M.R. (2014) Assessing tectonic and climatic causal mechanisms in foreland-basin stratal architecture: insights from the Alborz Mountains, northern Iran. Earth Surf. Proc. Land., 39 (1), 110-125.

Ballato, P., Uba, C.E., Landgraf, A., Strecker, M.R., Sudo, M., Stockli, D.F., Friedrich, A. \& Tabatabaei, S.H. (2011) Arabia-Eurasia continental collision: insights from late Tertiary foreland-basin evolution in the Alborz Mountains, northern Iran. Geol. Soc. Am. Bull., 123 (1-2), 106-131.

Berberian, M. (1995) Master 'blind' thrust faults hidden under the Zagros folds: active basement tectonics and surface morphotectonics. Tectonophysics, 241 (3-4), 193-224.

Berberian, M. \& King, G.C.P. (1981) Towards a paleogeography and tectonic evolution of Iran. Can. F. Earth Sci., 18, 210-265.

Blanc, E.J.P., Allen, M.B., Inger, S. \& Hassani, H. (2003) Structural styles in the Zagros simple folded zone, Iran. $\mathcal{F}$. Geol. Soc., 160 (3), 401-412.

Bollinger, L., Avouac, J.P., Beyssac, O., Catlos, E.J., Harrison, T.M., Grove, M., Goffé, B. \& Sapkota, S. (2004) Thermal structure and exhumation history of the Lesser Himalaya in central Nepal. Tectonics, 23 (5), TC5015, doi:10. 1029/2003TC001564.

van Buchem, F.S.P., Allan, T.L., Laursen, G.V., Lotfpour, M., Moallemi, A., Monibi, S., Motiei, H., Pickard, N.A.H., Tahmasbi, A.R., Vedrenne, V. \& Vincent, B. (2010) Regional stratigraphic architecture and reservoir types of the Oligo-Miocene deposits in the Dezful Embayment (Asmari and Pabdeh Formations) SW Iran. Geol. Soc. Spec. Publ., 329 (1), 219-263.

Burke, W.H., Denison, R.E., Hetherington, E.A., Koepnick, R.B., Nelson, H.F. \& Otто, J.B. (1982) Variation of seawater $87 \mathrm{Sr} / 86 \mathrm{Sr}$ throughout phanerozoic time. Geology, 10 (10), 516-519.

Catuneanu, O. (2002) Sequence stratigraphy of clastic systems: concepts, merits, and pitfalls. F. Afr. Earth Sc., 35, 1-43.

Cross, T.A. (1986) Tectonic controls of foreland basin subsidence and laramide style deformation, Western United States. In: Foreland Basins (Ed. by P.A. Allen \& P. Homewood), pp. 13-39. Blackwell Publishing Ltd., Oxford, UK.

Dahlen, F.A. (1990) Critical taper model of fold-and-thrust belts and accretionary wedges. Annual Reviem of Earth and Planetary Sciences, 18(1), 55-99.
DeCelles, P.G. (2004) Late jurassic to eocene evolution of the cordilleran thrust belt and foreland basin system, western U.S.A. Am. F. Sci., 304 (2), 105-168.

DeCelles, P.G. \& Currie, B.S. (1996) Long-term sediment accumulation in the middle Jurassic-early Eocene Cordilleran retroarc foreland-basin system. Geology, 24 (7), 591-594.

DeCelles, P.G. \& DeCelles, P.C. (2001) Rates of shortening, propagation, underthrusting, and flexural wave migration in continental orogenic systems. Geology, 29 (2), 135-138.

DeCelles, P.G., Carrapa, B., Horton, B.K. \& Gehrels, G.E. (2011) Cenozoic foreland basin system in the central Andes of northwestern Argentina: implications for Andean geodynamics and modes of deformation: Andean Foreland Basin. Tectonics, 30 (6), TC6013, doi:10.1029/2011TC002948.

Ehrenberg, S.N., Pickard, N.A.H., Laursen, G.V., Monibi, S., Mossadegh, Z.K., Svånå, T.A., Agrawi, A.A.M., McArThur, J.M. \& Thirlwall, M.F. (2007) Strontium isotope stratigraphy of the Asmari Formation (oligocene-Lower Miocene), Sw Iran. 7. Petrol. Geol., 30 (2), 107-128.

Elderfield, H. (1986) Strontium isotope stratigraphy. Palaeogeogr. Palaeoclimatol. Palaeoecol., 57 (1), 71-90.

Emami, H. (2008) Foreland Propagation Folding and Structure of the Mountain Front Flexture in the Posht-e-kuh are. NW Zagros, Iran, $181 \mathrm{p}$.

Emami, H., Verges, J., Nalpas, T., Gillespie, P., Sharp, I., Karpuz, R., Blanc, E.P. \& Goodarzi, M.G.H. (2010) Structure of the Mountain Front Flexure along the Anaran anticline in the Pusht-e Kuh Arc (NW Zagros, Iran): insights from sand box models. Geol. Soc. Spec. Publ., 330 (1), 155-178.

Fakhari, M.D., Axen, G.J., Horton, B.K., Hassanzadeh, J. \& Amini, A. (2008) Revised age of proximal deposits in the Zagros foreland basin and implications for Cenozoic evolution of the High Zagros. Tectonophysics, 451 (1-4), 170-185.

Gavillot, Y., Axen, G.J., Stockli, D.F., Horton, B.K. \& FAKHARI, M.D. (2010) Timing of thrust activity in the High Zagros fold-thrust belt, Iran, from (U-Th)/He thermochronometry. Tectonics, 29 (4), TC4025, doi:10.1029/2009TC0 02484.

Hessami, K., Koyi, H. A., Talbot, C. J., Tabasi, H. \& ShabaNIAN, E. (2001) Progressive unconformities within an evolving foreland fold-thrust belt, Zagros Mountains. Fournal of the Geological Society of London, 158 (Part 6), 969-981.

Hessami, K., Nilforoushan, F. \& Talbot, C.J. (2006) Active deformation within the Zagros Mountains deduced from GPS measurements. F. Geol. Soc., 163 (1), 143-148.

HeYDARI, E. (2008) Tectonics versus eustatic control on supersequences of the Zagros Mountains of Iran. Tectonophysics, 451 (1-4), 56-70.

Hodell, D.A., Mueller, P.A. \& Garrido, J.R. (1991) Variations in the strontium isotopic composition of seawater during the Neogene. Geology, 19 (1), 24-27.

Homke, S., Vergés, J., Garcés, M., Emami, H. \& Karpuz, R. (2004) Magnetostratigraphy of Miocene-Pliocene Zagros foreland deposits in the front of the Push-e Kush Arc (Lurestan Province, Iran). Earth Planet. Sci. Lett., 225 (3-4), 397410.

Horton, B.K., Constenius, K.N. \& DeCelles, P.G. (2004) Tectonic control on coarse-grained foreland-basin sequences: an example from the Cordilleran foreland basin. Utah Geol., 32 (7), 637-640.

JACKSON, J.A. (1980) Reactivation of basement faults and crustal shortening in orogenic belts. Nature, 283 (5745), 343-346. Published online: 24 January 1980; doi:10.1038/283343a0. 
Jahani, S., Callot, J.-P., Letouzey, J. \& Lamotte, D.F.d. (2009) The eastern termination of the Zagros Fold-andThrust Belt, Iran: structures, evolution, and relationships between salt plugs, folding, and faulting. Tectonics, 28, TC6004, doi:10.1029/2008TC002418.

James, G.A. \& WYND, J.G. (1965) Stratigraphic nomenclature of Iranian oil consortium agreement area. AAPG Bull., 49 (12), 2182-2245.

KASHFI, M.S. (1980) Stratigraphy and environmental sedimentology of lower Fars Group (Miocene), South-Southwest Iran. AAPG Bull., 64, 2095-2107.

KENT, P.E. (1979) The emergent Hormuz salt plugs of southern Iran. 7. Pet. Geol, 2 (2), 117-144.

Khadivi, S., Mouthereau, F., Larrasoaña, J.C., Vergés, J., Lacombe, O., Khademi, E., Beamud, E., Melinte-DobrineSCU, M. \& SuC, J.P. (2010) Magnetochronology of synorogenic Miocene foreland sediments in the Fars arc of the Zagros Folded Belt (SW Iran). Basin Res., 22 (6), 918-932.

Khadivi, S., Mouthereau, F., Barbarand, J., Adatte, T. \& LACOMBE, O. (2012) Constraints on palaeodrainage evolution induced by uplift and exhumation on the southern flank of the Zagros-Iranian Plateau. 7. Geol. Soc., 169 (1), 83-97.

Koop, W.J., Stoneley, R., Ridd, M.F., MurPhy, R.W., OsmasTON, M.F. \& KHolief, M.M. (1982) Subsidence history of the Middle east Zagros basin, permian to recent [and Discussion]. Philos. Trans. Phys. Sci. Eng., 305 (1489), 149-168.

Lavé, J. \& Avouac, J.P. (2001) Fluvial incision and tectonic uplift across the Himalayas of central Nepal. 7. Geophys. Res., 106 (B11), 26561-26591.

McArthur, J.M. \& Howarth, R.J. (2004) Strontium Isotope Stratigraphy In: A Geologic Time Scale 2004 (Ed. by F.M. Gradstein, J.G. Ogg \& A.G. Smith), Vol. 7, pp. 96-105. Cambridge University Press, Cambridge, England.

McArthur, J.M., Howarth, R.J. \& Bailey, T.R. (2001) Strontium isotope stratigraphy: LOWESS Version 3: best fit to the marine sr-isotope curve for 0-509 $\mathrm{Ma}$ and accompanying look-up table for deriving numerical Age. 7. Geol., 109 (2), 155-170.

McKenzie, J.A., Hodell, D.A., Mueller, P.A. \& Mueller, D.W. (1988) Application of strontium isotopes to late miocene-early pliocene stratigraphy. Geology, 16 (11), 1022-1025.

McQuarrie, N. \& van Hinsbergen, D.J.J. (2013) Retrodeforming the Arabia-Eurasia collision zone: age of collision versus magnitude of continental subduction. Geology, 41 (3), 315318.

Miller, K.G., Kominz, M.A., Browning, J.V., Wright, J.D., Mountain, G.S., Katz, M.E., Sugarman, P.J., Cramer, B.S., Christie-Blick, N. \& Pekar, S.F. (2005) The phanerozoic record of global sea-level change. Science, 310 (5752), $1293-1298$.

Molinaro, M., Leturmy, P., Guezou, J.C., Frizon de LamotTe, D. \& Eshraghi, S.A. (2005) The structure and kinematics of the southeastern Zagros fold-thrust belt, Iran: from thin-skinned to thick-skinned tectonics. Tectonics, 24 (3), TC3007, doi:10.1029/2004TC001633.

Morris, P. (1977) Basement structure as suggested by aeromagnetic surveys in southwest Iran: Geological Suryay of Iran. Second geological symposium of Iran.

Motiei, H. (1993) Stratigraphy of Zagros. Geological Survey of Iran, Tehran, $536 \mathrm{p}$.

Mouthereau, F. (2011) Timing of uplift in the Zagros belt/Iranian plateau and accommodation of late Cenozoic ArabiaEurasia convergence. Geol. Mag., 148 (5-6), 726-738.
Mouthereau, F., Tensi, J., Bellahsen, N., Lacombe, O., Boisgrollier, T.D. \& Kargar, S. (2007) Tertiary sequence of deformation in a thin-skinned/thick-skinned collision belt: the Zagros Folded Belt (Fars, Iran). Tectonics, 26 (5), TC5006, doi:10.1029/2007TC002098.

Mugnier, J.-L. \& Huyghe, P. (2006) Ganges basin geometry records a pre-15 Ma isostatic rebound of Himalaya. Geology, 34, 445-448.

Painter, C.S. \& Carrapa, B. (2013) Flexural versus dynamic processes of subsidence in the North American Cordillera foreland basin. Geophys. Res. Lett., 40 (16), 4249-4253.

Paul, A., Hatzfeld, D., Kaviani, A., Tatar, M. \& Péquegnat, C. (2010) Seismic imaging of the lithospheric structure of the Zagros mountain belt (Iran). Geol. Soc. Spec. Publ., 330 (1), 5-18.

Pfiffner, O.A., Schlunegger, F. \& Buiter, S.J.H. (2002) The Swiss Alps and their peripheral foreland basin: stratigraphic response to deep crustal processes. Tectonics, 21 (2), 3-1-3-16.

Pirouz, M. (2013) The geometry and sedimentary record of tectonics in the Neogene Zagros foreland basin. PhD. Geneva, $135 \mathrm{p}$.

Pirouz, M., Simpson, G., Bahroudi, A. \& Azhdari, A. (2011) Neogene sediments and modern depositional environments of the Zagros foreland basin system. Geol. Mag., 148 (5-6), 838853.

Poole, F.G. (1974) Flysch deposits of the antler foreland basin, western United States: tectonics and sedimentation. Soc. Econ. Paleontol. Mineral. Spec. Publ., 22, 58-82.

Reilinger, R., McClusky, S., Vernant, P., Lawrence, S., Ergintav, S., Cakmak, R., Ozener, H., Kadirov, F., Guliev, I., Stepanyan, R., Nadariya, M., Hahubia, G., Mahmoud, S., Sakr, K., ArRajehi, A., Paradissis, D., Al-Aydrus, A., Prilepin, M., Guseva, T., Evren, E., Dmitrotsa, A., Filikov, S.V., Gomez, F., Al-Ghazzi, R. \& Karam, G. (2006) GPS constraints on continental deformation in the AfricaArabia-Eurasia continental collision zone and implications for the dynamics of plate interactions. F. Geophys. Res., 111 (B5), B05411, doi:10.1029/2005JB004051.

RicCi LucCHI, F. (1986) The oligocene to recent foreland basins of the northern apennines. In: Foreland Basins (Ed. by P.A. Allen \& P. Homewood), pp. 103-139. Blackwell Publishing Ltd., Oxford, UK.

Saura, E., Vergés, J., Homke, S., Blanc, E., Serra-Kiel, J., Bernaola, G., Casciello, E., Fernández, N., Romaire, I., Casini, G., Embry, J.C., Sharp, I.R. \& Hunt, D.W. (2011) Basin architecture and growth folding of the NW Zagros early foreland basin during the Late Cretaceous and early Tertiary. 7. Geol. Soc., 168 (1), 235-250.

Sepenr, M. \& Cosgrove, J.W. (2004) Structural framework of the Zagros Fold - Thrust Belt, Iran. Mar. Petrol. Geol., 21 (7), 829-843.

Sepehr, M. \& Cosgrove, J.W. (2005) Role of the Kazerun Fault Zone in the formation and deformation of the Zagros FoldThrust Belt, Iran. Tectonics, 24 (5), TC5005, doi:10.1029/ 2004TC001725.

Setudehnia, A. (1972) International stratigraphic Lexicon of Iran: south-west Iran. Inter. Union Geol. Sci., 3, 287-376.

Sherkati, S. \& Letouzey, J. (2004) Variation of structural style and basin evolution in the central Zagros (Izeh zone and Dezful Embayment), Iran. Mar. Petrol. Geol., 21 (5), 535-554.

Sinclair, H.D. (1997a) Flysch to molasse transition in peripheral foreland basins: the role of the passive margin versus slab breakoff. Geology, 25 (12), 1123-1126. 
SinclaIR, H.D. (1997b) Tectonostratigraphic model for underfilled peripheral foreland basins: an Alpine perspective. Geol. Soc. Am. Bull., 109 (3), 324-346.

Sinclair, H.D. \& Allen, P.A. (1992) Vertical versus horizontal motions in the Alpine orogenic wedge: stratigraphic response in the foreland basin. Basin Res., 4 (3-4), 215-232.

SNYDER, D.B. \& Barazangi, M. (1986) Deep crustal structure and flexure of the Arabian Plate Beneath the Zagros collisional mountain belt as inferred from gravity observations. Tectonics, $5(3), 361-373$.

STocklin, J. (1968) Structural history and tectonics of Iran: a review. AAPG Bull., 52, 1229-1258.

TAKIN, M. (1972) Iranian geology and continental drift in the Middle East. Nature, 235 (5334), 147-150.

Talbot, C.J. \& Alavi, M. (1996) The past of a future syntaxis across the Zagros. Geol. Soc. Spec. Publ., 100 (1), 89-109.

Talebian, M. \& Jackson, J. (2004) A reappraisal of earthquake focal mechanisms and active shortening in the Zagros mountains of Iran. Geophys. 7. Int., 156 (3), 506-526.

Tatar, M., Hatzfeld, D., Martinod, J., Walpersdorf, A., GHAFori-Ashtiany, M. \& ChÉry, J. (2002) The present-day deformation of the central Zagros from GPS measurements.
Geophys. Res. Lett., 29, 1927-1930, doi:10.1029/ 2002 GL015427.

Vergés, J., Fernàndez, M. \& Martìnez, A. (2002) The Pyrenean orogen: pre-, syn-, and post-collisional evolution. 7 Virtual Exp., 8, 55-74.

Vergés, J., Saura, E., Casciello, E., Fernàndez, M., Villaseñor, A., Jiménez-Munt, I. \& García-Castellanos, D. (2011) Crustal-scale cross-sections across the NW Zagros belt: implications for the Arabian margin reconstruction. Geol. Mag., 148 (5-6), 739-761.

Walpersdorf, A., Hatzfeld, D., Nankali, H., Tavakoli, F., Nilforoushan, F., Tatar, M., Vernant, P., Chéry, J. \& Masson, F. (2006) Difference in the GPS deformation pattern of North and Central Zagros (Iran). Geophys. F. Int., 167 (3), 1077-1088.

Manuscript received 27 January 2014; In revised form 14 October 2014; In revised form 14 October 2014.

\section{APPENDIX A}

\begin{tabular}{|c|c|c|c|c|c|c|c|c|c|c|}
\hline No & Location & Sample & $\begin{array}{l}\text { Min. } \\
\text { age }\end{array}$ & $\begin{array}{l}\text { Age } \\
(\mathrm{Ma})\end{array}$ & $\begin{array}{l}\text { Max. } \\
\text { age }\end{array}$ & ${ }^{87} \mathrm{Sr} /{ }^{86} \mathrm{Sr}$ & Error & Formation & L.A. & $\begin{array}{l}\text { Location }(\mathrm{X}, \mathrm{Y}) \text {, } \\
\text { Decimal Degree }\end{array}$ \\
\hline 1 & Zarinabad & $\mathrm{Z}$ & 16.042 & 16.199 & 16.364 & 0.7087075379 & 0.0000032544 & $\begin{array}{c}\text { Base of the } \\
\text { Mishan }\end{array}$ & $\mathrm{MN}_{\mathrm{L}}$ & $\left(46.849360^{\circ}, 33.001219^{\circ}\right)$ \\
\hline 2 & Gatvand & G & 15.632 & 15.782 & 15.926 & 0.7087337988 & 0.0000036139 & $\begin{array}{l}\text { Base of the } \\
\text { Mishan }\end{array}$ & $\mathrm{MN}_{\mathrm{L}}$ & $\left(48.936942^{\circ}, 32.217760^{\circ}\right)$ \\
\hline 3 & $\begin{array}{l}\text { Masjed } \\
\text { Solayman }\end{array}$ & MS1 & 12.979 & 13.630 & 14.644 & 0.7088046212 & 0.0000042243 & $\begin{array}{l}\text { Top of the } \\
\text { Mishan }\end{array}$ & $\mathrm{MN}_{\mathrm{L}}$ & $\left(49.144565^{\circ}, 32.060090^{\circ}\right)$ \\
\hline 4 & $\begin{array}{l}\text { Masjed } \\
\text { Solayman }\end{array}$ & MS2 & 16.479 & 16.722 & 16.964 & 0.7086774269 & 0.0000071215 & $\begin{array}{l}\text { Base of the } \\
\text { Mishan }\end{array}$ & $\mathrm{MN}_{\mathrm{L}}$ & $\left(49.145337^{\circ}, 32.061063^{\circ}\right)$ \\
\hline 5 & Haftkel & $\mathrm{H}$ & 12.382 & 12.815 & 13.307 & 0.7088186217 & 0.0000037557 & $\begin{array}{l}\text { Top of the } \\
\text { Mishan }\end{array}$ & $\mathrm{MN}_{\mathrm{M}}$ & $\left(49.520989^{\circ}, 31.502225^{\circ}\right)$ \\
\hline 6 & Agha Jari & AJ & 15.365 & 15.521 & 15.691 & 0.7087499563 & 0.0000045176 & $\begin{array}{c}\text { Base of the } \\
\text { Mishan }\end{array}$ & $\mathrm{MN}_{\mathrm{L}}$ & $\left(49.715861^{\circ}, 30.784517^{\circ}\right)$ \\
\hline 7 & Sepidar & S & 9.712 & 9.954 & 10.219 & 0.7088878457 & 0.0000021092 & Middle Mishan & $\mathrm{MN}_{\mathrm{M}}$ & $\left(53.181856^{\circ}, 28.846822^{\circ}\right)$ \\
\hline 8 & Kaftar & K1 & 15.668 & 15.807 & 15.937 & 0.7087321764 & 0.0000028934 & $\begin{array}{l}\text { Base of the } \\
\text { Mishan }\end{array}$ & $\mathrm{MN}_{\mathrm{U}}$ & $\left(53.136757^{\circ}, 28.824337^{\circ}\right)$ \\
\hline 9 & Kaftar & K2 & 16.964 & 17.159 & 17.362 & 0.7086520861 & 0.0000052322 & $\begin{array}{l}\text { Base of the } \\
\text { Mishan }\end{array}$ & $\mathrm{MN}_{\mathrm{U}}$ & $\left(53.137042^{\circ}, 28.825165^{\circ}\right)$ \\
\hline 10 & Gach & GA1 & 11.638 & 12.123 & 12.500 & 0.7088339422 & 0.0000021113 & Upper Mishan & $\mathrm{MN}_{\mathrm{M}}$ & $\left(54.421042^{\circ}, 28.141708^{\circ}\right)$ \\
\hline 11 & Gach & GA2 & 12.413 & 12.806 & 13.245 & 0.7088188217 & 0.0000029202 & Lower Mishan & $\mathrm{MN}_{\mathrm{R}}$ & $\left(54.417141^{\circ}, 28.139289^{\circ}\right)$ \\
\hline 12 & Siah & SI1 & 8.922 & 9.329 & 9.664 & 0.7089090048 & 0.0000024119 & Upper Mishan & $\mathrm{MN}_{\mathrm{M}}$ & $\left(54.333422^{\circ}, 27.553558^{\circ}\right)$ \\
\hline 13 & Siah & SI2 & 9.914 & 10.196 & 10.509 & 0.7088794538 & 0.0000030557 & Middle Mishan & $\mathrm{MN}_{\mathrm{M}}$ & $\left(54.334410^{\circ}, 27.557935^{\circ}\right)$ \\
\hline 14 & Nakh & N1 & 6.497 & 6.738 & 7.053 & 0.7089617465 & 0.0000043928 & Middle Mishan & $\mathrm{MN}_{\mathrm{M}}$ & $\left(54.592669^{\circ}, 27.090225^{\circ}\right)$ \\
\hline 15 & Nakh & $\mathrm{N} 2$ & 9.644 & 9.925 & 10.227 & 0.7088888241 & 0.0000033580 & Guri member & $\mathrm{MN}_{\mathrm{R}}$ & $\left(54.606354^{\circ}, 27.096550^{\circ}\right)$ \\
\hline 16 & Nakh & N3 & 13.583 & 14.478 & 14.786 & 0.7087973461 & 0.0000015078 & Lower Mishan & $\mathrm{MN}_{\mathrm{L}}$ & $\left(54.607207^{\circ}, 27.098267^{\circ}\right)$ \\
\hline 17 & Nakh & $\mathrm{N} 4$ & 15.117 & 15.291 & 15.418 & 0.7087659299 & 0.0000027380 & Lower Mishan & $\mathrm{MN}_{\mathrm{L}}$ & $\left(54.608071^{\circ}, 27.098956^{\circ}\right)$ \\
\hline 18 & Asaluyeh & $\mathrm{A} 1$ & 7.304 & 7.587 & 8.316 & 0.7089392755 & 0.0000026076 & Middle Mishan & $\mathrm{MN}_{\mathrm{M}}$ & $\left(52.683609^{\circ}, 27.587958^{\circ}\right)$ \\
\hline 19 & Asaluyeh & A2 & 7.524 & 7.911 & 8.631 & 0.7089330956 & 0.0000024249 & Middle Mishan & $\mathrm{MN}_{\mathrm{M}}$ & $\left(52.679356^{\circ}, 27.584448^{\circ}\right)$ \\
\hline
\end{tabular}

(continued) 


\section{Pirouz et al.}

Table (continued)

\begin{tabular}{|c|c|c|c|c|c|c|c|c|c|c|}
\hline No & Location & Sample & $\begin{array}{l}\text { Min. } \\
\text { age }\end{array}$ & $\begin{array}{l}\text { Age } \\
(\mathrm{Ma})\end{array}$ & $\begin{array}{l}\text { Max. } \\
\text { age }\end{array}$ & ${ }^{87} \mathrm{Sr} /{ }^{86} \mathrm{Sr}$ & Error & Formation & L.A. & $\begin{array}{l}\text { Location }(\mathrm{X}, \mathrm{Y}) \text {, } \\
\text { Decimal Degree }\end{array}$ \\
\hline 20 & Mand & M1 & 5.450 & 5.565 & 5.668 & 0.7090168152 & 0.0000021935 & Upper Mishan & $\mathrm{MN}_{\mathrm{M}}$ & $\left(51.285513^{\circ}, 28.268886^{\circ}\right)$ \\
\hline 21 & Mand & M2 & 9.663 & 9.925 & 10.206 & 0.7088888357 & 0.0000027001 & Middle Mishan & $\mathrm{MN}_{\mathrm{M}}$ & $\left(51.289894^{\circ}, 28.272787^{\circ}\right)$ \\
\hline 22 & Charak & $\mathrm{C}$ & 2.997 & 3.955 & 4.628 & 0.7090533950 & 0.0000053106 & Middle Mishan & $\mathrm{MN}_{\mathrm{M}}$ & $\left(54.309737^{\circ}, 26.795252^{\circ}\right)$ \\
\hline 23 & Qeshm & Q1 & 1.866 & 2.081 & 2.261 & 0.7090830249 & 0.0000030139 & Upper Mishan & $\mathrm{MN}_{\mathrm{M}}$ & $\left(55.909904^{\circ}, 26.866000^{\circ}\right)$ \\
\hline 24 & Qeshm & Q2 & 1.859 & 2.156 & 2.405 & 0.7090807449 & 0.0000054795 & Upper Mishan & $\mathrm{MN}_{\mathrm{M}}$ & $\left(55.940417^{\circ}, 26.843406^{\circ}\right)$ \\
\hline 25 & Qeshm & Q3 & 4.350 & 4.702 & 4.915 & 0.7090439851 & 0.0000031887 & Middle Mishan & $\mathrm{MN}_{\mathrm{M}}$ & $\left(55.899270^{\circ}, 26.879970^{\circ}\right)$ \\
\hline 26 & Qeshm & Q4 & 11.024 & 11.436 & 12.062 & 0.7088452359 & 0.0000036789 & Middle Mishan & $\mathrm{MN}_{\mathrm{M}}$ & $\left(55.910813^{\circ}, 26.865739^{\circ}\right)$ \\
\hline 27 & Qeshm & Q5 & 11.044 & 11.446 & 12.052 & 0.7088450759 & 0.0000033189 & Middle Mishan & $\mathrm{MN}_{\mathrm{M}}$ & $\left(55.920378^{\circ}, 26.850626^{\circ}\right)$ \\
\hline 28 & Bostaneh & $\mathrm{B} 1$ & 0.948 & 1.070 & 1.174 & 0.7091340847 & 0.0000042876 & Upper Mishan & $\mathrm{MN}_{\mathrm{M}}$ & $\left(54.855097^{\circ}, 26.573801^{\circ}\right)$ \\
\hline 29 & Bostaneh & $\mathrm{B} 2$ & 1.528 & 1.641 & 1.780 & 0.7090974549 & 0.0000029458 & Upper Mishan & $\mathrm{MN}_{\mathrm{M}}$ & $\left(54.874809^{\circ}, 26.575719^{\circ}\right)$ \\
\hline 30 & Bostaneh & B3 & 5.343 & 5.510 & 5.638 & 0.7090193352 & 0.0000032181 & Middle Mishan & $\mathrm{MN}_{\mathrm{M}}$ & $\left(54.864630^{\circ}, 26.596274^{\circ}\right)$ \\
\hline 31 & Bostaneh & B4 & 5.859 & 5.978 & 6.087 & 0.7089950753 & 0.0000044399 & Middle Mishan & $\mathrm{MN}_{\mathrm{M}}$ & $\left(54.847375^{\circ}, 26.608582^{\circ}\right)$ \\
\hline
\end{tabular}

